\title{
Intra-colonial diversity in the scleractinian coral, Acropora millepora: identifying the nutritional gradients underlying physiological integration and compartmentalised functioning
}

\author{
Jessica A Conlan ${ }^{\text {Corresp., }}{ }^{1}$, Craig A Humphrey ${ }^{2}$, Andrea Severati ${ }^{2}$, David S Francis \\ ${ }^{1}$ School of Life and Environmental Science, Deakin University, Warrnambool, Victoria, Australia \\ 2 The National Sea Simulator, Australian Institute of Marine Science, Townsville, Queensland, Australia \\ Corresponding Author: Jessica A Conlan \\ Email address: conlan@deakin.edu.au
}

Scleractinian corals are colonial organisms comprising multiple physiologically integrated polyps and branches. Colonialism in corals is highly beneficial, and allows a single colony to undergo several life processes at once through physiological integration and compartmentalised functioning. Elucidating differences in the biochemical composition of intra-colonial branch positions will provide valuable insight into the nutritional reserves underlying different regions in individual coral colonies. This will also ascertain prudent harvesting strategies of wild donor-colonies to generate coral stock with high survival and vigour prospects for reef-rehabilitation efforts and captive husbandry. This study examined the effects of colony branch position on the nutritional profile of two different colony sizes of the common scleractinian, Acropora millepora. For smaller colonies, branches were sampled at three locations: the colony centre (S-centre), $50 \%$ of the longitudinal radius length (LRL) (S-50), and the colony edge (S-edge). For larger colonies, four locations were sampled: the colony centre (L-centre), 33.3\% of the LRL (L-33), $66.6 \%$ of the LRL (L-66), and the edge (L-edge). Results demonstrate significant branch position effects, with the edge regions containing higher protein, likely due to increased tissue synthesis and calcification. Meanwhile, storage lipid and total fatty acid concentrations were lower at the edges, possibly reflecting catabolism of high-energy nutrients to support proliferating cells. Results also showed a significant effect of colony size in the two classes examined. While the major protein and structural lipid sink was exhibited at the edge for both sizes, the major sink for high-energy lipids and fatty acids appeared to be the L-66 position of the larger colonies and the S-centre and S-50 positions for the smaller colonies. These results confirm that the scleractinian coral colony is not nutritionally homogeneous, and while different regions of the coral colony are functionally specialised, so too are their nutritional profiles geared toward meeting specific energetic demands. 
1 Intra-colonial diversity in the scleractinian coral, Acropora

2 millepora: identifying the nutritional gradients underlying

3 physiological integration and compartmentalised functioning

5 Conlan, J A. ${ }^{1,2, *}$, Humphrey, C.A. ${ }^{2}$, Severati, A. ${ }^{2}$, and D.S. Francis ${ }^{1}$

$6{ }^{1}$ Deakin University, Geelong, Australia. School of Life and Environmental Sciences,

7 Warrnambool Campus. Princes Hwy, Sherwood Park. PO Box 423, Warrnambool, VIC 3280

$8 \quad{ }^{2}$ The National Sea Simulator; Australian Institute of Marine Science, PMB No3, Townsville,

9 QLD 4810, Australia.

$10 \quad$ *Corresponding author (jessconlan@live.com.au) 


\section{Abstract}

12 Scleractinian corals are colonial organisms comprising multiple physiologically integrated polyps

13 and branches. Colonialism in corals is highly beneficial, and allows a single colony to undergo

14 several life processes at once through physiological integration and compartmentalised

15 functioning. Elucidating differences in the biochemical composition of intra-colonial branch

16 positions will provide valuable insight into the nutritional reserves underlying different regions in

17 individual coral colonies. This will also ascertain prudent harvesting strategies of wild donor-

18 colonies to generate coral stock with high survival and vigour prospects for reef-rehabilitation

19 efforts and captive husbandry. This study examined the effects of colony branch position on the

20 nutritional profile of two different colony sizes of the common scleractinian, Acropora millepora.

21 For smaller colonies, branches were sampled at three locations: the colony centre (S-centre), 50\%

22 of the longitudinal radius length (LRL) (S-50), and the colony edge (S-edge). For larger colonies,

23 four locations were sampled: the colony centre (L-centre), 33.3\% of the LRL (L-33), 66.6\% of

24 the LRL (L-66), and the edge (L-edge). Results demonstrate significant branch position effects,

25 with the edge regions containing higher protein, likely due to increased tissue synthesis and

26 calcification. Meanwhile, storage lipid and total fatty acid concentrations were lower at the edges,

27 possibly reflecting catabolism of high-energy nutrients to support proliferating cells. Results also

28 showed a significant effect of colony size in the two classes examined. While the major protein

29 and structural lipid sink was exhibited at the edge for both sizes, the major sink for high-energy

30 lipids and fatty acids appeared to be the L-66 position of the larger colonies and the S-centre and

31 S-50 positions for the smaller colonies. These results confirm that the scleractinian coral colony

32 is not nutritionally homogeneous, and while different regions of the coral colony are functionally

33 specialised, so too are their nutritional profiles geared toward meeting specific energetic

34 demands. 


\section{Introduction}

36 Scleractinian corals are colonial organisms comprising multiple asexually produced and

37 physiologically integrated polyps (Oren et al., 2001; Bone \& Keough, 2010). The colonial nature

38 of scleractinian corals is highly beneficial, with modular coral colonies being able to attain large

39 increases in size and volume isometrically, allowing the component units to remain small

40 (Vollmer \& Edmunds, 2000; Hughes, 2005). This reduces the chance of whole colony mortality

41 and increases colony exposure to exploitable environmental factors, such as sunlight and nutrition

42 sources (Nakamura \& Yamasaki, 2006; Bone \& Keough, 2010).

43 Physiological integration also permits resource translocation from branches growing in

44 favourable microhabitats to those growing under more adverse conditions (Hemond, Kaluziak \&

45 Vollmer, 2014; Nozawa \& Lin, 2014). This is made possible through interconnecting tissues and

46 a shared gastrovascular system (Hemond, Kaluziak \& Vollmer, 2014). Individual polyps can thus

47 act as cooperative systems, buffering negative microhabitat effects, colonising hostile areas, and

48 permitting resource sharing should some polyps fail to capture food or light (Murdock, 1978;

49 Gateno et al., 1998; Bone \& Keough, 2010).

50 Additionally, intracolonial transport of essential resources via the gastrovascular system enables

51 transference from established regions into zones of maximal energetic demand (Taylor, 1977).

52 For example, organic products (lipids, glycerol, and glucose) have been shown to be translocated

53 from established branch bases to growing tips, in order to contribute to calcification and tissue

54 synthesis (Fang, Chen \& Chen, 1989; Oren, Rinkevich \& Loya, 1997). Established colony areas

55 face less competitive interactions and are no longer undergoing rapid growth, and thus possess

56 higher energy reserves (Oku et al., 2002). Meanwhile, growing regions with proliferating cells

57 have higher metabolic rates and thus greater energetic demand (Gladfelter, Michel \& Sanfelici,

58 1989; Oku et al., 2002). 
59 Different colony regions can also be specialised for specific functions. For example, established

60 colony regions are generally the most fecund, while the growing regions are often sexually

61 sterile, and dedicated to growth and asexual reproduction (Nozawa \& Lin, 2014). Such

62 compartmentalisation of functional roles transcends to physiological processes. It is therefore

63 reasonable to hypothesise that this, in turn, should manifest in zonation of nutritional resources

64 and bioactive compounds, since different nutrients are required to fuel different life processes

65 (Sargent et al., 1999b). For example, the quantity and nature of coral lipids and their constituent

66 fatty acids (FA) varies significantly with photosynthesis, respiration, heterotrophy, cell

67 replenishment, and reproduction (Ward, 1995; Leuzinger, Anthony \& Willis, 2003; Imbs, 2013).

68 In particular, high photosynthesis rates can be characterised by an abundance of carbon-rich

69 compounds (Muscatine, 1990), while heterotrophically-derived nutrients are richer in nitrogen

70 and phosphorus (Houlbrèque \& Ferrier-Pagès, 2009). Additionally, protein fuels tissue growth,

71 and calcification (Conlan, Rocker \& Francis, 2017), as well as high metabolic rates in corals

72 (Oku et al., 2002).

73 While numerous studies have examined intra-colonial variation in the biochemical composition

74 along a single coral branch (i.e. branch base-tip) (Taylor, 1977; Fang, Chen \& Chen, 1989;

75 Gladfelter, Michel \& Sanfelici, 1989; Oku et al., 2002; Tang et al., 2015), these results provide

76 little insight into nutritional processes within the entire colony. To date, comprehensive analyses

77 expanding these findings to nutritional variation between colony regions (i.e. colony centre-edge)

78 has yet to be conducted. Identifying nutritional compartmentalisation in coral colonies in toto

79 would augment current understanding of the nutritional resources driving functional roles in

80 healthy coral today, which is fundamental in informing coral reef research and management

81 practices in the future. 
82 Elucidating intracolonial variation in the nutritional profile may also facilitate an improved

83 harvesting strategy of wild donor coral colonies, permitting judicious selection of branches with

84 maximal survival, growth, and vigour prospects following fragmentation and translocation for

85 reef rehabilitation efforts and captive husbandry (Olivotto et al., 2011; Leal et al., 2016).

86 Increased global awareness of coral reef degradation has resulted in the development of

87 rehabilitation strategies including fragmentation and translocation, to enable rapid regeneration of

88 degraded reef sites (Forsman et al., 2015). However, fragmentation and translocation are highly

89 stressful events for coral, and reports of successful cultivation from fragmented branches are

90 sparse (Arvedlund, Craggs \& Pecorelli, 2003; Leal et al., 2016).

91 Fragmentation causes tissue loss, lesions, and colony size reduction, which leads to an extensive

92 and vulnerable recovery period (Smith \& Hughes, 1999; Lirman, 2000a). This is exacerbated by

93 translocation into foreign conditions, where water quality, temperature, light, and feed availability

94 can vary significantly from the environment of origin. Importantly, the size and quality of initial

95 energy reserves have been shown to significantly influence coral survivorship following stressful

96 events (Anthony et al., 2009; Sheridan et al., 2013). As such, identifying the colony branch

97 locations that possess 'optimal' nutritional profiles would be advantageous to buffer the stressors

98 associated with fragmentation and translocation.

99 In addition, since coral colony size has been shown to influence several physiological aspects,

100 including energy allocation to growth (Anthony, Connolly \& Willis, 2002), reproduction

101 (Nozawa \& Lin, 2014), and primary production (Jokiel \& Morrissey, 1986), the nutritional

102 drivers behind these processes should also vary with colony size. As such, this study sought to

103 test two hypotheses; 1) that coral branch biochemical composition will differ depending on its

104 originating position within the colony, and 2) that colony size will influence the regional trends in

105 branch biochemical composition. Here, we examined the nutritional composition along the 
106 longitudinal radius of two different size classes of a common, broadcast spawning scleractinian

107 coral, Acropora millepora. The growth of A. millepora is characterised by radiate, skeletal

108 accretion which manifests as multiple finger-like branches arrayed in roughly two dimensions.

\section{Materials and Methods}

\section{Sample collection}

111 Sampling was conducted at depths of 2.6 - 5.4 m at Davies Reef in the Great Barrier Reef,

112 Queensland, Australia (lat.: $-18^{\circ} 49.948^{\prime}$ S, long.:147 $37.995^{\prime} \mathrm{E}$ ) on the $9^{\text {th }}$ of June, 2015. Ten

113 colonies of two size classes of Acropora millepora were sampled (Field collections were

114 approved by the Great Barrier Reef Marine Park Authority: G12/35236.1). The two size classes

115 were larger: $4376 \pm 741 \mathrm{~cm}^{2}$, and smaller: $1410 \pm 88 \mathrm{~cm}^{2}$ (planar surface area), which represented

116 two common size classes in the sampling area. For each colony, two replicate, adjacent branches

117 were sampled from each location. For larger colonies, four locations were sampled: the centre of

118 the colony (L-centre), $33.3 \%$ of the longitudinal radius length (L-33), $66.6 \%$ of the longitudinal

119 radius length (L-66), and at the edge (L-edge) (Fig. 1a). For smaller colonies, branches were

120 sampled at three locations: the centre of the colony (S-centre), $50 \%$ of the longitudinal radius

121 length (S-50), and the edge of the colony (S-edge) (Fig. 1b).

\section{Zooxanthellae densities}

123 Zooxanthellae were extracted using the air-spraying technique (Szmant \& Gassman, 1990).

124 Tissue was removed from the coral skeleton using a jet of high-pressure air from a hand gun (80

125 psi, $1 \mathrm{~cm}$ distance to coral). All sprayed tissue was captured in a thick, polyethylene bag 
127 from the plastic bag into a falcon tube, and the bag was double-rinsed with ultrafiltered seawater

128 that was also collected. The slurry was then homogenised for $20 \mathrm{~s}$ (Ultra-Turrax T10B; IKA

129 Labortechnik, Staufenim Breisgau, Germany). A $500 \mathrm{uL}$ aliquot of tissue slurry was taken and

130 combined with a $500 \mathrm{uL}$ aliquot of $3 \%$ formalin: filtered seawater for preservation.

131 Zooxanthellae were counted in triplicate using a haemocytometer. Zooxanthellae densities were

132 then standardised to branch surface area $\left(\mathrm{cm}^{2}\right)$, which was obtained through the simple geometry

133 technique, which has been shown to be suitable for Acropora spp. (Naumann et al., 2009), using

134 the software, Fiji ImageJ (Schindelin et al., 2012).

\section{Proximate analysis}

136 Proximate analysis refers to the measurement of the relative amounts protein, lipid, moisture, ash,

137 and carbohydrate in an organism. Once the zooxanthellae aliquot was taken, the tissue slurry and

138 denuded skeletons were freeze-dried for $72 \mathrm{hrs}$. Following freeze-drying, the denuded skeletons

139 were placed inside a stainless steel mortar and pestle (cleaned with methanol), which was placed

140 inside a manual laboratory hydraulic press (Model C; Fred S. Carver Inc., Summit, NJ, USA),

141 and pressurised to $70 \mathrm{kN}$, crushing the corals to a fine powder. This powder was then recombined

142 with the dried tissue to account for organic material present in both the coral skeleton and tissue

143 (Conlan, Rocker \& Francis, 2017). The recombined coral powder was then extracted for total

144 lipid content according to the method described in Conlan et al. (2014). Dry samples were

145 weighed then soaked overnight in a $3 \mathrm{~mL}$ aliquot of dichloromethane: methanol

$146\left(\mathrm{CH}_{2} \mathrm{Cl}_{2}: \mathrm{CH}_{3} \mathrm{OH}\right)$. The following morning, this mixture was filtered and the solid residue re-

147 suspended and soaked for a further $10 \mathrm{~min}$ with another $3 \mathrm{~mL}$ aliquot of $\mathrm{CH}_{2} \mathrm{Cl}_{2}: \mathrm{CH}_{3} \mathrm{OH}$,

148 followed by a further filtration step. This process was repeated three times. The combined 
149 filtrates $(\sim 9 \mathrm{~mL})$ were then transferred into a separation funnel and combined with a $4.5 \mathrm{~mL}$ 150 sample washing solution of $\mathrm{KCl}(0.44 \%)$ in $\mathrm{H}_{2} \mathrm{O} / \mathrm{CH}_{3} \mathrm{OH}(3: 1)$. The mixture was shaken and 151 allowed to settle overnight. The following morning, the bottom layer containing the extracted

152 lipid was recovered and the solvent was evaporated under nitrogen. The lipid content was then

153 quantified to four decimal places. Protein content was determined according to the Kjeldahl

154 method (crude protein calculated as nitrogen $\times 6.25$ ) in an automated Kjeltech (Tecator, Sweden).

155 Total ash was determined by incineration in a muffle furnace (C \& L Fetlow, Model WIT,

156 Blackburn, Victoria, Australia) at $450{ }^{\circ} \mathrm{C}$ for $12 \mathrm{~h}$. The ash content was subtracted from the total

157 composition to obtain ash free dry weight (AFDW), which excludes the inorganic component.

158 Carbohydrate/ nitrogen free extract (NFE) was obtained by subtracting the ash, lipid, and protein

159 from the total sample mass. Energy was calculated using the combustion enthalpies for lipid

160 (39.5 $\left.\mathrm{J} \mathrm{mg}^{-1}\right)$ and protein (23.9 $\mathrm{J} \mathrm{mg}^{-1}$ ) from Gnaiger \& Bitterlich (1984).

\section{Lipid class and fatty acid analysis}

162 Lipid class analysis was determined using an Iatroscan MK 6s thin layer chromatography-flame

163 ionisation detector (Mitsubishi Chemical Medience, Tokyo Japan) according to the method of

164 Conlan et al (2014). Each sample was spotted in duplicate on silica gel S5-chromarods (5 $\mu \mathrm{m}$

165 particle size) with lipid separation following a two-step elution sequence: 1)

166 phosphatidylethanolamine (PE), phosphatidylcholine (PC) and lysophosphatidylchloline (LPC)

167 elution was achieved in a dichloromethane/methanol/water (50:20:2, by volume) solvent system

168 run to half height ( $\sim 15 \mathrm{~min}$ ); and 2) after air drying, wax ester (WAX), triacylglycerol (TAG),

169 free fatty acid (FFA), 1,2-diacylglycerol (1,2DAG), and sterol (ST) elution was achieved in a

170 hexane/diethyl ether/formic acid (60:15:1.5, by volume) solvent system run to full height $(\sim 30$ 
$171 \mathrm{~min})$. Since glycolipids commonly elute with monoacylglycerols and pigments, including

172 chlorophyll, the term "acetone mobile polar lipid" (AMPL) was used in the present study

173 (Parrish, Bodennec \& Gentien, 1996). AMPL was quantified using the 1-monopalmitoyl glycerol

174 standard (Sigma-Aldrich Co., USA), which has demonstrated a response that is intermediate

175 between glycoglycerolipids and pigments (Parrish, Bodennec \& Gentien, 1996).

176 Following initial lipid extraction, FA were esterified into methyl esters using an acid-catalysed

177 methylation method and then analysed by gas chromatography as described in Conlan et al 178 (2014).

\section{Statistical analysis}

180 Data were analysed using R software version 2.3.1 (RStudio Team, 2015; R Development Core

181 Team, 2016). Due to non-normality and heteroscedasticity (detected via Shapiro-Wilk and

182 Levene's tests, respectively), as well as some negative values, data were transformed using a Yeo-

183 Johnson power transformation (caret package (Kuhn, 2016)). Transformed data were then

184 analysed using a one-way analysis of variance (ANOVA) for each parameter measured. Where

185 statistical differences were detected, a TukeyHSD post-hoc test was employed at a significance

186 level of $P<0.05$ (agricolae package (de Meniburu, 2015)). FA profiles (mg g lipid ${ }^{-1}$ ) were also

187 analysed using a linear discriminant analysis (LDA), in order to visualize the relationships

188 between colony position (MASS package (Venables \& Ripley, 2002)). An LDA biplot was

189 included to show the top fifteen FA driving the differences between colony position. The colour

190 gradient of the vectors show percentage contribution to LDA loadings. Ellipses show 95\%

191 confidence intervals. Figures were prepared using the ggplot2 package (Wickham, 2009). 


\section{Results}

\section{Proximate composition and zooxanthellae density}

194 For the larger colonies, the zooxanthellae densities at the edge were lower than the next

195 immediate position, L-66 (cells $\left.\mathrm{cm}^{2-1}\right)$ (Fig. 2a), although this was not statistically significant $(P-$

$\left.196{ }_{A N O V A}>0.05, P_{H S D}>0.05\right)$. On the other hand, the smaller colonies recorded significantly lower

197 zooxanthellae densities at the edge in comparison to the centre $\left(P_{A N O V A}<0.05, P_{H S D}<0.05\right)$.

198 The caloric enthalpies showed that, for both size classes, the edge and next immediate position

199 contained the highest energy contents, while the S-centre, L-centre, and L-33 positions were low 200 (Fig. 2b). Although these differences were not significant for the smaller colonies $\left(P_{A N O V A}>0.05\right.$, $\left.201 P_{H S D}>0.05\right)$, for the larger colonies, the L-33 position was significantly lower compared to the L20266 position $\left(P_{A N O V A}<0.01, P_{H S D}<0.01\right)$ as well as the edge $\left(P_{A N O V A}<0.01, P_{H S D}<0.05\right)$.

203 Within the size classes, there were no significant differences in total lipid $\left(P_{A N O V A}>0.05, P_{H S D}>\right.$ 204 0.05) (mg g sample ${ }^{-1}$ (Fig. 2c), although both edge positions contained lower lipid compared to 205 the next, immediate position. Within both size classes, there was a progressive increase in protein 206 from the colony centre toward the edge $\left(\mathrm{mg} \mathrm{g} \mathrm{sample}^{-1}\right)$ (Fig. 2d). For the larger colonies, protein 207 at the edge was significantly higher than the centre $\left(P_{A N O V A}<0.05, P_{H S D}<0.05\right)$, while for the 208 smaller colonies, the edge was significantly higher than the centre and S-50 positions $\left(P_{A N O V A}<\right.$ $\left.2090.01, P_{H S D}<0.01\right)$.

\section{Lipid class composition}

211 Storage lipids consist of the classes WAX, TAG, FFA, and 1,2-DAG, while structural lipids 212 consist of ST, AMPL, PE, PS-PI, and PC. The storage lipid proportion in the larger colonies 213 followed a similar trend to the total lipid concentration, with the L-66 position containing the 
214 highest storage lipids, although this was not statistically significant $\left(\mathrm{mg} \mathrm{g} \mathrm{lipid}^{-1}\right)\left(P_{A N O V A}>0.05\right.$,

$\left.215 P_{H S D}>0.05\right)$ (Fig. 3a). Similarly, in the smaller colonies, the edge recorded the lowest storage

216 lipid concentration, and this was significant compared to the S-centre and S-50 positions $\left(P_{A N O V A}<\right.$

$\left.2170.05, P_{H S D}<0.05\right)$ (Fig. 3b, Table 1).

218 Neither size class recorded significant differences in TAG concentration between sites $\left(P_{\text {ANOVA }}>\right.$

$\left.2190.05, P_{H S D}>0.05\right)$. However, the highest TAG concentration in the larger colonies was recorded at

220 L-66, and at the centre position for the smaller colonies. AMPL was significantly higher at S-

221 edge in comparison to the centre and S-50 $\left(P_{A N O V A}<0.05, P_{H S D}<0.05\right)$. For the larger colonies, the

222 highest AMPL concentrations were found at the edge and L-33 positions, which were

223 significantly higher than the L-66 $\left(P_{A N O V A}<0.05, P_{H S D}<0.05\right)$.

\section{Fatty acid and fatty alcohol composition}

225 In both size classes, the edge positions contained the lowest total FA concentration (S-edge: $347 \pm$

$22658.6 \mathrm{mg} \mathrm{g} \mathrm{lipid}^{-1}$ and L-edge: $\left.382 \pm 52.6 \mathrm{mg} \mathrm{g} \mathrm{lipid}^{-1}\right)\left(P_{A N O V A}<0.01\right)($ Table 2$)$. In the smaller

227 colonies, the highest total FA were found in the centre $\left(519 \pm 75.1 \mathrm{mg} \mathrm{g} \mathrm{lipid}^{-1}\right)$, which was

228 significantly higher compared to the edge $\left(P_{H S D}<0.01\right)$. The larger colonies contained the highest

229 total FA in the L-66 position $\left(547 \pm 66 \mathrm{mg} \mathrm{g} \mathrm{lipid}^{-1}\right)$, which was significantly higher than the L-33

230 and edge positions $\left(P_{H S D}<0.05\right)$. These trends extended to the individual FA $\left(\mathrm{mg} \mathrm{g} \mathrm{lipid}^{-1}\right)$.

231 Notably, DHA showed a distal decrease from the centre to the edge in the smaller colonies (S-

232 centre: $16.9 \pm 3.02 \mathrm{mg} \mathrm{g} \mathrm{lipid}{ }^{-1}-$ S-edge: $\left.11.1 \pm 2.29 \mathrm{mg} \mathrm{g} \mathrm{lipid}^{-1}\right)\left(P_{A N O V A}<0.05, P_{H S D}<0.05\right)$, yet

233 in the larger colonies was found in the highest concentrations in the L-66 position $(17 \pm 2.47 \mathrm{mg}$

$\left.234 \mathrm{~g} \mathrm{lipid}^{-1}\right)$, and the lowest in the L-33 and edge positions $\left(\sim 12 \mathrm{mg} \mathrm{g} \mathrm{lipid}^{-1}\right)\left(P_{A N O V A}>0.05, P_{H S D}>\right.$

235 0.05). This was mirrored in the total PUFA concentrations for both size classes. ARA was an 
236 exception, being present in the highest concentrations at the edge, regardless of size class $\left(P_{A N O V A}\right.$

$237<0.05)$.

238 When viewed as \% FA, the edge positions recorded significantly higher PUFA concentrations

239 compared to all other positions for the smaller colonies $\left(P_{A N O V A}<0.01, P_{H S D}<0.01\right)$, and compared

240 to the centre and L-66 position for the larger colonies (Table 3$)\left(P_{A N O V A}<0.01, P_{H S D}<0.05\right)$. The

241 edge positions also contained the lowest saturated fatty acids (SFA) concentrations, and this was

242 significant compared to the centre and L-66 positions for the larger colonies $\left(P_{A N O V A}<0.01, P_{H S D}<\right.$

$2430.05)$.

244 In the LDA of the FA composition $\left(\mathrm{mg} \mathrm{g} \mathrm{lipid}^{-1}\right)$, the first two linear discriminates explained 83.3

$245 \%$ of the total variation between size classes and colony positions (Fig. 4a), with an established

246 Wilks value of 0.0004 . The analysis showed a clear difference between the smaller and larger

247 colonies, with the smaller colonies grouping mostly on the positive side of LD1 and negative side

248 of LD2, and the larger showing the inverse. Despite this separation, both size classes followed the

249 same trends. There was clear separation of the edge positions from centre positions. The middle

250 regions (S-50, L-33, L-66) largely grouped between their respective centre and edge positions.

251 The overlapping of the S-centre and S-50 groups illustrates the similarity between these

252 positions, as well as for the L-33, L-66, and L-centre positions.

253 The LDA biplot (Fig. 4b) shows that the size class separation was largely due to 18 DMA for the

254 small colonies, while 22:6n-3 (DHA), 16:1n-7, and 18:n-6 drove the larger colony separation.

255 Separation of the two edge positions was strongly influenced by the polyunsaturated fatty acids

256 (PUFA) 18:3n-6, 20:5n-3 (EPA), and 20:4n-6 (ARA) as well as the SFA 14:0 and 20:0, and the

257 monounsaturated fatty acid (MUFA), 18:1n-9. Meanwhile, the centre positions were largely

258 influenced by 16:0, 22:4n-6, 20:1n-11, and 20:3n-6. 


\section{Discussion}

260 The present study examined the biochemical composition along the longitudinal radius of $A$.

261 millepora colonies, providing a unique account of nutritional resource compartmentalisation

262 stemming from branch position and functional specialisation within a single coral colony. These

263 findings provide new insights into colony-wide zonation of the comprehensive nutritional profile

264 from a length-wise (i.e. colony centre-edge) perspective since, until now, previous studies have

265 been limited to individual coral branches from a height-wise (i.e. branch base-tip) perspective

266 (Taylor, 1977; Fang, Chen \& Chen, 1989; Gladfelter, Michel \& Sanfelici, 1989; Oku et al., 2002;

267 Tang et al., 2015).

\section{Total protein concentration and zooxanthellae densities}

269 Since growth of branching scleractinian corals is characterised by radiate skeletal accretion, the

270 colony edges generally undergo the greatest growth rates (Kaandorp, 1995). This can account for

271 the significant, distal increase in total protein from the centre regions toward the edge recorded in

272 both colony size classes. High protein levels are characteristic of actively growing sites, where

273 protein synthesis and retention facilitates calcification, tissue and polyp production (Mitterer,

274 1978; Conlan, Rocker \& Francis, 2017). These results agree well with previous studies on the

275 nutritional profile of individual soft coral branches (base-tip), which showed increases in protein

276 concentration at the actively growing tip, compared to the established base (Tentori \& Allemand,

277 2006; Tentori \& Thomson, 2008). However, these results show that when individual branches are

278 analysed as a whole, the mean protein concentrations of each branch position manifests in a

279 nutritional gradient from the colony centre toward the edge that is parallel to that of an individual

280 branch from the base toward the tip. This indicates that a coral colony exhibits similar nutritional 
281 gradients in two dimensions; height-wise (i.e. base-tip) and length-wise (i.e. centre-edge), and

282 that the latter trend is manifestly stronger than the former.

283 The significantly lower zooxanthellae densities recorded at the smaller colony edges is again

284 comparable to growing branch tips, where newly formed tissues are yet to be fully colonised by

285 symbionts (Goreau, 1959; Gladfelter, Michel \& Sanfelici, 1989), further demonstrating the

286 similarities between height-wise and length-wise gradients within a coral colony. In contrast, the

287 lowest zooxanthellae densities in the larger colonies were akin to the most dense region in the

288 smaller colonies, possibly due to their larger size, as larger coral colonies are suggested to

289 undergo more rapid zooxanthellae proliferation compared to smaller colonies (Muscatine,

290 Mccloskey \& Loya, 1985).

\section{Total lipid, lipid classes, and fatty acids}

292 Although zooxanthellae densities are directly correlated with lipid concentrations in corals (Fang,

293 Chen \& Chen, 1989), the lower density at the colony edges of smaller corals did not correlate

294 with low total lipid concentrations. This may suggest an increase in heterotrophic feeding by the

295 edge regions to supplement the reduced phototrophic nutrient supply (Lesser, 2012; Levas et al.,

296 2015). The increased protein concentrations at the edges support this, since exogenous food is

297 known to supply nitrogen-rich building blocks needed for tissue and skeletal biosynthesis

298 (Osinga et al., 2011). Alternatively, this may indicate intracolonial lipid translocation from the

299 established, zooxanthellae-dense regions toward the colony edge (Fang, Chen \& Chen, 1989).

300 Inner colony regions generally acquire an energy surplus, since photosynthesis greatly exceeds

301 respiration and competitive interactions are reduced (Gladfelter, Michel \& Sanfelici, 1989;

302 Lirman, 2000a). As such, energy accumulated by the inner regions can be mobilised via the

303 coral's gastrovascular system and concentrated in zones of maximal energetic demand, such as

304 the growing edge (Oren, Brickner \& Loya, 1998; Bone \& Keough, 2010; Marfenin, 2015). 
305 Within the total lipid concentration, storage lipids (WAX, TAG, FFA, and 1,2-DAG) are generally

306 associated with energy supply, while structural lipids (ST, AMPL, PE, PS-PI, and PC) are

307 important cell membrane constituents, facilitating cell membrane fluidity and permeability, and

308 performing vital cell signalling processes (Lee, Hagen \& Kattner, 2006; Ferrier-Pagès et al.,

309 2016). As such, the significantly lower storage lipid concentrations at the edges of the smaller

310 colonies may reflect lipid catabolism to supply the energy demanded by proliferating cells (Oku

311 et al., 2002; Denis et al., 2013). Concurrently, the increased structural lipid proportion likely

312 reflects tissue synthesis, since ST and phospholipids constitute the building blocks of cell

313 membranes (Imbs et al., 2010).

314 In contrast to the smaller colonies, there were no significant differences in storage lipid

315 concentrations between positions for the larger colonies. This may suggest a shift in inner region

316 function of the larger colonies, such that they have transitioned from nutrient assimilation to

317 nutrient remobilisation - allowing the rest of the colony to benefit from their accumulated

318 reserves, as has been shown in colonial plants (Avila-Ospina et al., 2014). Interestingly, although

319 the combustion enthalpy for protein $\left(23.9 \mathrm{~J} \mathrm{mg}^{-1}\right)$ is far lower than lipid $\left(39.5 \mathrm{~J} \mathrm{mg}^{-1}\right)($ Gnaiger \&

320 Bitterlich, 1984), the high protein at the edges manifested in energy levels similar to the positions

321 containing the maximum lipid concentrations, demonstrating the substantial allocation of

322 metabolic resources to colony growth (Ramos-Silva et al., 2014).

323 The trends between the smaller and larger colonies extended to the total FA concentrations (mg g

324 lipid $^{-1}$ ) whereby significantly higher concentrations were found in the centre position for the

325 smaller colonies, and the L-66 position for the larger colonies. This conforms to the lipid class

326 results in these positions, which contained higher TAG concentrations, which comprises three

327 esterified FA, while the edge is higher in phospholipids and ST, which possess two or less

328 esterified FA (Lee, Hagen \& Kattner, 2006). The total FA trends were reflected in most individual 
329 FA concentrations and indicate that these positions, along with the edges, represent the major

330 energy sinks in their respective colony sizes.

331 Notably, the S-centre, S-50, and L-66 positions exhibited significantly higher SFA and MUFA

332 concentrations, largely due to 14:0, 16:0, and 18:1n-9. These FA are known to be energy-rich and

333 readily catabolised, and are largely derived from zooxanthellae, corresponding to the high

334 zooxanthellae densities at these positions (Figueiredo et al., 2012). Furthermore, large reserves of

335 energy-rich lipid constituents, including TAG, SFA, and MUFA, are typically associated with

336 coral reproduction; an energetically expensive life process (Figueiredo et al., 2012). Since corals

337 must partition metabolic energy amongst several important physiological processes (Leuzinger,

338 Willis \& Anthony, 2012), the predominance of these compounds in the L-66, S-centre, and S-50

339 positions implicate these regions as being reproductively active. This correlates with the findings

340 of Nozawa \& Lin (2014), who showed that polyps obtained from the L-50 position of large

341 Acropora hyacinthus colonies had the highest fecundity levels, while the highest fecundity was

342 detected in the centre and S-50 positions of smaller colonies.

343 In contrast, the edge positions were conspicuously low in these readily catabolised materials,

344 conforming to both the lower zooxanthellae densities and the well-documented sterility of

345 actively growing regions in Acropora colonies (Hemond, Kaluziak \& Vollmer, 2014; Nozawa \&

346 Lin, 2014). Correspondingly, the edges contained significantly higher PUFA proportions (\% FA),

347 which are known to be major cell membrane constituents and are required for high growth and

348 development rates (Brett \& Muller-Navara, 1997; Sargent et al., 1999a).

349 These results clearly show that the scleractinian coral colony is not nutritionally homogeneous.

350 While different colony regions are functionally specialised for specific roles, so too are their

351 nutritional profiles different, demonstrating tight integration of a single coral colony such that, 
352 while individual regions must undergo a trade-off for resource allocation, the colony as a whole is

353 able to undergo several important life functions at once.

\section{Considerations for coral harvesting}

355 These results also provide fundamental information for prudent harvesting strategies of wild

356 donor coral colonies to generate stock for aquaculture, the aquarium trade (Olivotto et al., 2011;

357 Leal et al., 2016), and translocation to degraded reef sites (Miyazaki, Keshavmurthy \& Funami,

358 2010; Toh et al., 2013). Coral fragmentation and translocation corals is a highly stressful event,

359 and the speed at which recovery occurs is critical to survival and ongoing health (Lirman, 2000b;

360 Roff, Hoegh-Guldberg \& Fine, 2006). Since storage lipids and their constituent FA represent

361 important energy reserves during stressful periods for coral (Imbs \& Yakovleva, 2011; Denis et

362 al., 2013), judicious selection of branches inherently rich in these compounds will maximise their

363 survival and recovery prospects. Indeed, it has been shown that there is a significant, inverse

364 relationship between initial coral lipid stores and the onset timing of high mortality rates

365 following major stress events (Anthony et al., 2009). Concordantly, branches undergoing rapid

366 growth, which contain lower storage lipid reserves, have shown lowered regenerative capacities

367 (Oren et al., 2001; Roff, Hoegh-Guldberg \& Fine, 2006; Denis et al., 2013). Considering this, the

368 results of the present study suggest that the L-66 position of the larger size class (4376 \pm 741

$\left.369 \mathrm{~cm}^{2}\right)$, and the S-centre and S-50 positions of the smaller size class $\left(1410 \pm 88 \mathrm{~cm}^{2}\right)$, are

370 metabolically-active branches containing large stores of energy-rich lipids and not undergoing

371 rapid growth - thus representing positions with the greatest survival and health prospects

372 following fragmentation and translocation. 


\section{Acknowledgements:}

374 The authors thank the SeaSim team at AIMS and the staff of Deakin University's School of Life

375 and Environmental Sciences for technical assistance throughout the project. This work conforms 376 to the legal requirements of Australia. 
377

378

379

380

381

382

383

384

385

386

387

388

389

390

391

392

393

394

395

396

397

398

399

400

401

402

403

404

405

406

407

408

409

410

411

412

413

414

415

\section{References}

Anthony KRN., Connolly SR., Willis BL. 2002. Comparative analysis of energy allocation to tissue and skeletal growth in corals. Limnology and Oceanography 47:1417-1429. DOI: 10.4319/lo.2002.47.5.1417.

Anthony KRN., Hoogenboom MO., Maynard JA., Grottoli A., Middlebrook R. 2009. Energetics approach to predicting mortality risk from environmental stress: A case study of coral bleaching. Functional Ecology 23:539-550. DOI: 10.1111/j.1365-2435.2008.01531.x.

Arvedlund M., Craggs J., Pecorelli J. 2003. Coral Culture — Possible Future Trends and Directions. In: Cato J, Brown C eds. Marine Ornamental Species: Collection, Culture and Conservation. Iowa State Press,.

Avila-Ospina L., Moison M., Yoshimoto K., Masclaux-Daubresse C. 2014. Autophagy, plant senescence, and nutrient recycling. Journal of Experimental Botany 65:3799-3811. DOI: $10.1093 / \mathrm{jxb} / \mathrm{eru} 039$.

Bone EK., Keough MJ. 2010. Does polymorphism predict physiological connectedness? A test using two encrusting bryozoans. Biological Bulletin 219:220-230.

Brett M., Muller-Navara D. 1997. The role of highly unsaturated fatty acids in aquatic foodweb processes. Freshwater Biology 38:483-499.

Conlan J., Jones P., Turchini G., Hall M., Francis D. 2014. Changes in the nutritional composition of captive early-mid stage Panulirus ornatus phyllosoma over ecdysis and larval development. Aquaculture 434:159-170.

Conlan JA., Rocker MM., Francis DS. 2017. A comparison of two common sample preparation techniques for lipid and fatty acid analysis in three different coral morphotypes reveals quantitative and qualitative differences. PeerJ 5:e3645. DOI: 10.7717/peerj.3645.

Denis V., Guillaume MMM., Goutx M., de Palmas S., Debreuil J., Baker AC., Boonstra RK., Bruggemann JH. 2013. Fast growth may impair regeneration capacity in the branching coral Acropora muricata. PloS one 8:e72618. DOI: 10.1371/journal.pone.0072618.

Fang LS., Chen Y., Chen CS. 1989. Why does the white tip of stony coral grow so fast without zooxanthellae? Marine Biology 103:359-363.

Ferrier-Pagès C., Godinot C., D'Angelo C., Wiedenmann J., Grover R. 2016. Phosphorus metabolism of reef organisms with algal symbionts. Ecological Monographs 86:262-277. DOI: $10.1002 / \mathrm{ecm} .1217$.

Figueiredo J., Baird AH., Cohen MF., Flot J-FF., Kamiki T., Meziane T., Tsuchiya M., Yamasaki H. 2012. Ontogenetic change in the lipid and fatty acid composition of scleractinian coral larvae. Coral Reefs 31:613-619. DOI: 10.1007/s00338-012-0874-3.

Forsman Z., Page CA., Toonen RJ., Vaughan D. 2015. Growing coral larger and faster: microcolony-fusion as a strategy for accelerating coral cover. PeerJ 3:e1313. DOI: 10.7717/peerj.1313.

Gateno D., Israel A., Barki Y., Rinkevich B. 1998. Gastrovascular circulation in an octocoral: Evidence of significant transport of coral and symbiont cells. Biological Bulletin 194:178- 
417 418

419

420

421

422

423

424

425

426

427

428

429

430

431

432

433

434

435

436

437

438

439

440

441

442

443

444

445

446

447

448

449

450

451

452

453

454

Gladfelter EH., Michel G., Sanfelici A. 1989. Metabolic gradients along a branch of the reef coral Acropora palmata. Bulletin of Marine Science 44:1166-1173.

Gnaiger E., Bitterlich G. 1984. Proximate biochemical composition and caloric content calculated from elemental CHN analysis: a stoichiometric concept. Oecologia 62:289-298. DOI: 10.1007/BF00384259.

Goreau T. 1959. The physiology of skeleton formation in corals. I. A method for measuring the rate of calcium deposition by corals under different conditions. Biological Bulletin 116:5975 .

Hemond EM., Kaluziak ST., Vollmer S V. 2014. The genetics of colony form and function in Caribbean Acropora corals. BMC genomics 15:1133. DOI: 10.1186/1471-2164-15-1133.

Houlbrèque F., Ferrier-Pagès C. 2009. Heterotrophy in tropical scleractinian corals. Biological reviews of the Cambridge Philosophical Society 84:1-17. DOI: 10.1111/j.1469185X.2008.00058.x.

Hughes RN. 2005. Lessons in modularity: the evolutionary ecology of colonial invertebrates. Scientia Marina 69:169-179. DOI: 10.3989/scimar.2005.69s1169.

Imbs AB. 2013. Fatty acids and other lipids of corals: Composition, distribution, and biosynthesis. Russian Journal of Marine Biology 39:153-168. DOI: 10.1134/S1063074013030061.

Imbs AB., Latyshev N., Dautova T., Latypov Y. 2010. Distribution of lipids and fatty acids in corals by their taxonomic position and presence of zooxanthellae. Marine Ecology Progress Series 409:65-75. DOI: 10.3354/meps08622.

Imbs AB., Yakovleva IM. 2011. Dynamics of lipid and fatty acid composition of shallow-water corals under thermal stress: an experimental approach. Coral Reefs 31:41-53. DOI: 10.1007/s00338-011-0817-4.

Jokiel PL., Morrissey JI. 1986. Influence of size on primary production in the reef coral Pocillopora damicornis and the macroalga Acanthophora spicifera. Marine Biology 91:1526.

Kaandorp JA. 1995. Analysis and synthesis of radiate accretive growth in three dimensions. Journal of theoretical biology 175:39-55. DOI: 10.1006/jtbi.1995.0119.

Kuhn M. 2016. caret: Classification and Regression Training.

Leal MC., Ferrier-Pagès C., Petersen D., Osinga R. 2016. Coral aquaculture: applying scientific knowledge to ex situ production. Reviews in Aquaculture 6:1-18. DOI: 10.1111/raq.12087.

Lee RF., Hagen W., Kattner G. 2006. Lipid storage in marine zooplankton. Marine Ecology Progress Series 307:273-306.

Lesser MP. 2012. Using energetic budgets to assess the effects of environmental stress on corals: are we measuring the right things? Coral Reefs 32:25-33. DOI: 10.1007/s00338-012-0993$\mathrm{x}$.

Leuzinger S., Anthony KRN., Willis BL. 2003. Reproductive energy investment in corals: scaling 
with module size. Oecologia 136:524-31. DOI: 10.1007/s00442-003-1305-5.

456

457

458

459

460

461

462

463

464

465

466

467

468

469

470

471

472

473

474

475

476

477

478

479

480

481

482

483

484

485

486

487

488

489

490

491

492

493

Leuzinger S., Willis BL., Anthony KRN. 2012. Energy allocation in a reef coral under varying resource availability. Marine Biology 159:177-186. DOI: 10.1007/s00227-011-1797-1.

Levas S., Grottoli AG., Schoepf V., Aschaffenburg M., Baumann J., Bauer JE., Warner ME. 2015. Can heterotrophic uptake of dissolved organic carbon and zooplankton mitigate carbon budget deficits in annually bleached corals? Coral Reefs:1-12. DOI: 10.1007/s00338-0151390-z.

Lirman D. 2000a. Lesion regeneration in the branching coral Acropora palmata: Effects of colonization, colony size, lesion size, and lesion shape. Marine Ecology Progress Series 197:209-215. DOI: 10.3354/meps197209.

Lirman D. 2000b. Fragmentation in the branching coral Acropora palmata (Lamarck): growth, survivorship, and reproduction of colonies and fragments. Journal of Experimental Marine Biology and Ecology 251:41-57. DOI: 10.1016/S0022-0981(00)00205-7.

Marfenin N. 2015. Non-radial symmetry of the transport system of Acropora corals. Invertebrate Zoology 12:53-59.

de Meniburu F. 2015. agricolae: Statistical procedures for agricultural research.

Mitterer M. 1978. Amino acid composition and metal binding capability of the skeletal protein of corals. Bulletin of Marine Science 28:173-180.

Miyazaki K., Keshavmurthy S., Funami K. 2010. Survival and growth of transplanted coral fragments in a high-latitude coral community (32 deg N) in Kochi, Japan. Kuroshio Biosphere 6:1-9.

Murdock GR. 1978. Digestion, assimilation and transport of food in the gastrovascular cavity of a gorgonian octocoral (Cnidaria; Anthozoa). Bulletin of Marine Science 28:354-362.

Muscatine L. 1990. The role of symbiotic algae in carbon and energy flux in coral reefs. In: Ecosystems of the world. 75-87.

Muscatine L., Mccloskey L., Loya Y. 1985. A comparison of the growth rates of zooxanthellae and animal tissue. Proceedings of the fifth international coral reef congress, Tahiti 6:119123.

Nakamura T., Yamasaki H. 2006. Morphological changes of pocilloporid corals exposed to water flow. Proceedings of the 10th International Coral Reef ... 875:872-875.

Naumann MS., Niggl W., Laforsch C., Glaser C., Wild C. 2009. Coral surface area quantification-evaluation of established techniques by comparison with computer tomography. Coral Reefs 28:109-117. DOI: 10.1007/s00338-008-0459-3.

Nozawa Y., Lin CH. 2014. Effects of colony size and polyp position on polyp fecundity in the scleractinian coral genus Acropora. Coral Reefs:1057-1066. DOI: 10.1007/s00338-0141185-7.

Oku H., Yamashiro H., Onaga K., Iwasaki H., Takara K. 2002. Lipid distribution in branching coral Montipora digitata. Fisheries Science 68:517-522. DOI: 10.1046/j.14442906.2002.00456.x. 
494

495

496

497

498

499

500

501

502

503

504

505

506

507

508

509

510

511

512

513

514

515

516

517

518

519

520

521

522

523

524

525

526

527

528

529

530

531

532

533

534

Olivotto I., Planas M., Simões N., Holt GJ., Avella MA., Calado R. 2011. Advances in Breeding and Rearing Marine Ornamentals. Journal of the World Aquaculture Society 42:135-166. DOI: $10.1111 /$ j.1749-7345.2011.00453.x.

Oren U., Benayahu Y., Lubinevsky H., Loya Y. 2001. Colony Integration during Regeneration in the Stony Coral Favia favus. Ecology 82:802-813.

Oren U., Brickner I., Loya Y. 1998. Prudent sessile feeding by the corallivore snail, Coralliophila violacea on coral energy sinks. Proceedings of the Royal Society B: Biological Sciences 265:2043-2050. DOI: 10.1098/rspb.1998.0538.

Oren U., Rinkevich B., Loya Y. 1997. Oriented intra-colonial transport of 14C labeled materials during coral regeneration. Marine Ecology Progress Series 161:117-122. DOI: $10.3354 /$ meps 161117.

Osinga R., Schutter M., Griffioen B., Wijffels RH., Verreth JAJ., Shafir S., Henard S., Taruffi M., Gili C., Lavorano S. 2011. The biology and economics of coral growth. Marine Biotechnology 13:658-671. DOI: 10.1007/s10126-011-9382-7.

Parrish CC., Bodennec G., Gentien P. 1996. Determination of glycoglyerolipids by Chromarod thin-layer chromatography with Iatroscan flame ionization detection. Journal of Chromatography 741:91-97.

R Development Core Team. 2016. R: A language and environment for statistical computing. $R$ Foundation for Statistical Computing Vienna, Au.

Ramos-Silva P., Kaandorp J., Herbst F., Plasseraud L., Alcaraz G., Stern C., Corneillat M., Guichard N., Durlet C., Luquet G., Marin F. 2014. The skeleton of the staghorn coral Acropora millepora: Molecular and structural characterization. PLoS ONE 9. DOI: 10.1371/journal.pone.0097454.

Roff G., Hoegh-Guldberg O., Fine M. 2006. Intra-colonial response to Acroporid "white syndrome" lesions in tabular Acropora spp. (Scleractinia). Coral Reefs 25:255-264. DOI: 10.1007/s00338-006-0099-4.

RStudio Team. 2015. RStudio: Integrated Development Environment for R.

Sargent J., Bell G., McEvoy L., Tocher D., Estevez A. 1999a. Recent developments in the essential fatty acid nutrition of fish. Aquaculture 177:191-199. DOI: 10.1016/S00448486(99)00083-6.

Sargent J., McEvoy L., Estevez A., Bell G., Bell M., Henderson J., Tocher D. 1999b. Lipid nutrition of marine fish during early development: current status and future directions. Aquaculture 179:217-229. DOI: 10.1016/S0044-8486(99)00191-X.

Schindelin J., Arganda-Carreras I., Frise E., Kaynig V., Longair M., Pietzsch T., Preibisch S., Rueden C., Saalfeld S., Schmid B., Tinevez J-Y., White DJ., Hartenstein V., Eliceiri K., Tomancak P., Cardona A. 2012. Fiji: an open-source platform for biological-image analysis. Nature methods 9:676-82. DOI: 10.1038/nmeth.2019.

Sheridan C., Kramarsky-Winter E., Sweet M., Kushmaro A., Leal MC. 2013. Diseases in coral aquaculture: Causes, implications and preventions. Aquaculture 396-399:124-135. DOI: 10.1016/j.aquaculture.2013.02.037.

Smith LD., Hughes TP. 1999. An experimental assessment of survival, re-attachment and 
535

536

537

538

539

540

541

542

543

544

545

546

547

548

549

550

551

552

553

554

555

556

557

558

559 fecundity of coral fragments. Journal of Experimental Marine Biology and Ecology 235:147-164. DOI: 10.1016/S0022-0981(98)00178-6.

Szmant AM., Gassman NJ. 1990. The effects of prolonged "bleaching" on the tissue biomass and reproduction of the reef coral Montastrea annularis. Coral Reefs 8:217-224. DOI: 10.1007/BF00265014.

Tang CH., Ku PC., Lin CY., Chen TH., Lee KH., Lee SH., Wang WH. 2015. Intra-Colonial Functional Differentiation-Related Modulation of the Cellular Membrane in a Pocilloporid Coral Seriatopora caliendrum. Marine Biotechnology 17:633-643. DOI: 10.1007/s10126015-9645-9.

Taylor DL. 1977. Intra-colonial transport of organic compounds and calcium in some atlantic reef corals. Proc. of the 3rd Int. Coral Reef Symp.:431-436.

Tentori E., Allemand D. 2006. Light-enhanced calcification and dark decalcification in isolates of the soft coral Cladiella sp. during tissue recovery. Biological Bulletin 211:193-202. DOI: $10.2307 / 4134593$.

Tentori E., Thomson M. 2008. Differential expression of soluble and membrane-bound proteins in soft corals (Cnidaria: Octocorallia). Marine And Freshwater Research:7-11.

Toh TC., Ng CSL., Guest J., Chou LM. 2013. Grazers improve health of coral juveniles in ex situ mariculture. Aquaculture 414-415:288-293. DOI: 10.1016/j.aquaculture.2013.08.025.

Venables WN., Ripley BD. 2002. Modern Applied Statistics with S. New York: Springer.

Vollmer S V., Edmunds PJ. 2000. Allometric scaling in small colonies of the scleractinian coral Siderastrea siderea (Ellis and Solander). Biological Bulletin 199:21-28. DOI: $10.2307 / 1542703$.

Ward S. 1995. Two patterns of energy allocation for growth, reproduction and lipid storage in the scleractinian coral Pocillopora damicornis. Coral Reefs 14:87-90.

Wickham H. 2009. ggplot2: Elegant Graphics for Data Analysis. New York: Springer-Verlag. 


\section{Figure legends}

\section{Figure 1}

562 Branch sampling locations of Acropora millepora colonies. (a) Larger colony $\left(4376 \pm 741 \mathrm{~cm}^{2}\right)$,

563 L-centre: colony centre, L-33: $33.3 \%$ of the longitudinal radius length, L-66: $66.6 \%$ of the

564 longitudinal radius length, L-edge: colony edge. (b) Smaller colony $\left(1410 \pm 88 \mathrm{~cm}^{2}\right)$, S-centre:

565 colony centre, S-50: $50 \%$ of the longitudinal radius length, S-edge: colony edge (S-edge). For

566 each size class, $\mathrm{n}=10$.

\section{Figure 2}

568 Proximate composition, energy content, and zooxanthellae density of distal intracolonial

569 locations in two size classes of Acropora millepora colonies. (a) Total lipid concentration, (b)

570 Total protein concentration, (c) Total nitrogen-free extract concentration (NFE), (d) Total ash

571 concentration, (e) Zooxanthellae density, (f) Energy content (using caloric enthalpies of lipid +

572 protein). L-centre: larger colony centre, L-33: $33.3 \%$ of the longitudinal radius length, L-66: 66.6

$573 \%$ of the longitudinal radius length, L-edge: larger colony edge, S-centre: smaller colony centre,

574 S-50: $50 \%$ of the longitudinal radius length, S-edge: smaller colony edge (S-edge). Values are

575 presented as means \pm SEM. Points denote individual samples. Letters in common denote no

576 significant difference $\left(P_{H S D}>0.05\right)$. For each size class, $\mathrm{n}=10$.

\section{Figure 3}

578 Lipid class composition - relative proportion of storage and structural lipids of distal intracolonial

579 locations in two size classes of Acropora millepora colonies. L-centre: larger colony centre, L-33:

$58033.3 \%$ of the longitudinal radius length, L-66: $66.6 \%$ of the longitudinal radius length, L-edge:

581 larger colony edge, S-centre: smaller colony centre, S-50: 50\% of the longitudinal radius length, 
582 S-edge: smaller colony edge (S-edge). Values are presented as means \pm SEM. Points denote

583 storage lipid concentration for individual samples. Letters in common denote no significant

584 difference $\left(P_{H S D}>0.05\right)$. For each size class, $\mathrm{n}=10$.

\section{Figure 4}

586 Linear discriminant analysis (LDA) a) score plot and b) biplot, showing overall fatty acid profile

$587\left(\mathrm{mg} \mathrm{g} \mathrm{lipid}^{-1}\right)$ of distal intracolonial locations in two size classes of Acropora millepora colonies.

588 L-centre: larger colony centre, L-33: $33.3 \%$ of the longitudinal radius length, L-66: $66.6 \%$ of the

589 longitudinal radius length, L-edge: larger colony edge, S-centre: smaller colony centre, S-50:

$59050 \%$ of the longitudinal radius length, S-edge: smaller colony edge (S-edge). a) Ellipses show

$59195 \%$ confidence intervals for each treatment. b) Vectors show top fifteen individual fatty acids

592 and fatty alcohols contributing to the overall variance between treatments. Colour gradient shows

593 percentage contribution to LDA loadings. For each size class, $n=10$. 


\section{Figure 1}

Branch sampling locations of Acropora millepora colonies.

(a) Larger colony $\left(4376 \pm 741 \mathrm{~cm}^{2}\right)$, L-centre: colony centre, L-33: $33.3 \%$ of the longitudinal radius length, L-66: $66.6 \%$ of the longitudinal radius length, L-edge: colony edge. (b) Smaller colony (1410 $\pm 88 \mathrm{~cm}^{2}$ ), S-centre: colony centre, S-50: $50 \%$ of the longitudinal radius length, S-edge: colony edge (S-edge). For each size class, $n=10$. 
(a)

$$
\text { L-centre L-33 } \quad \mathbf{6 6} \quad \text { Ledge }
$$

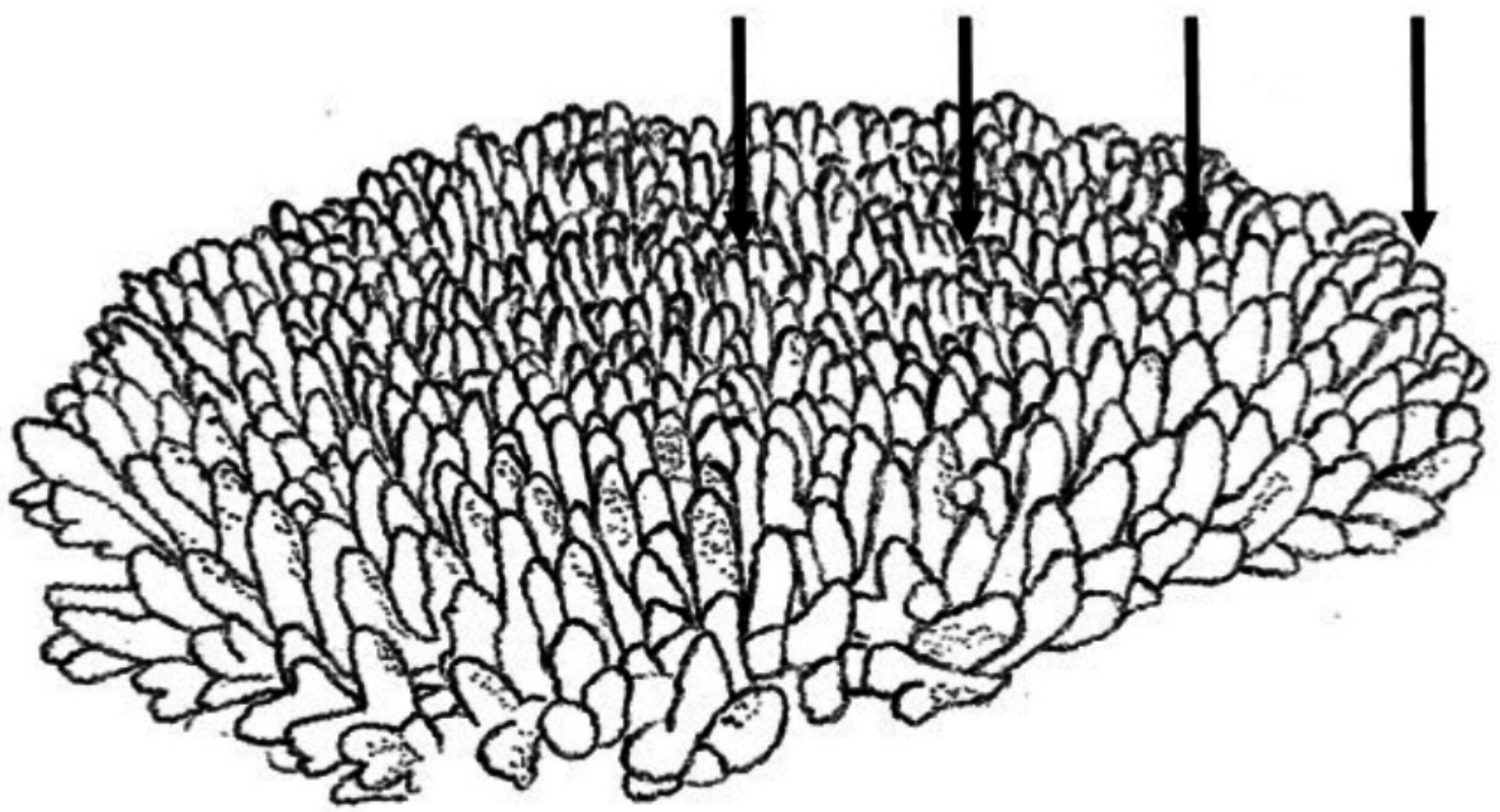

(b)

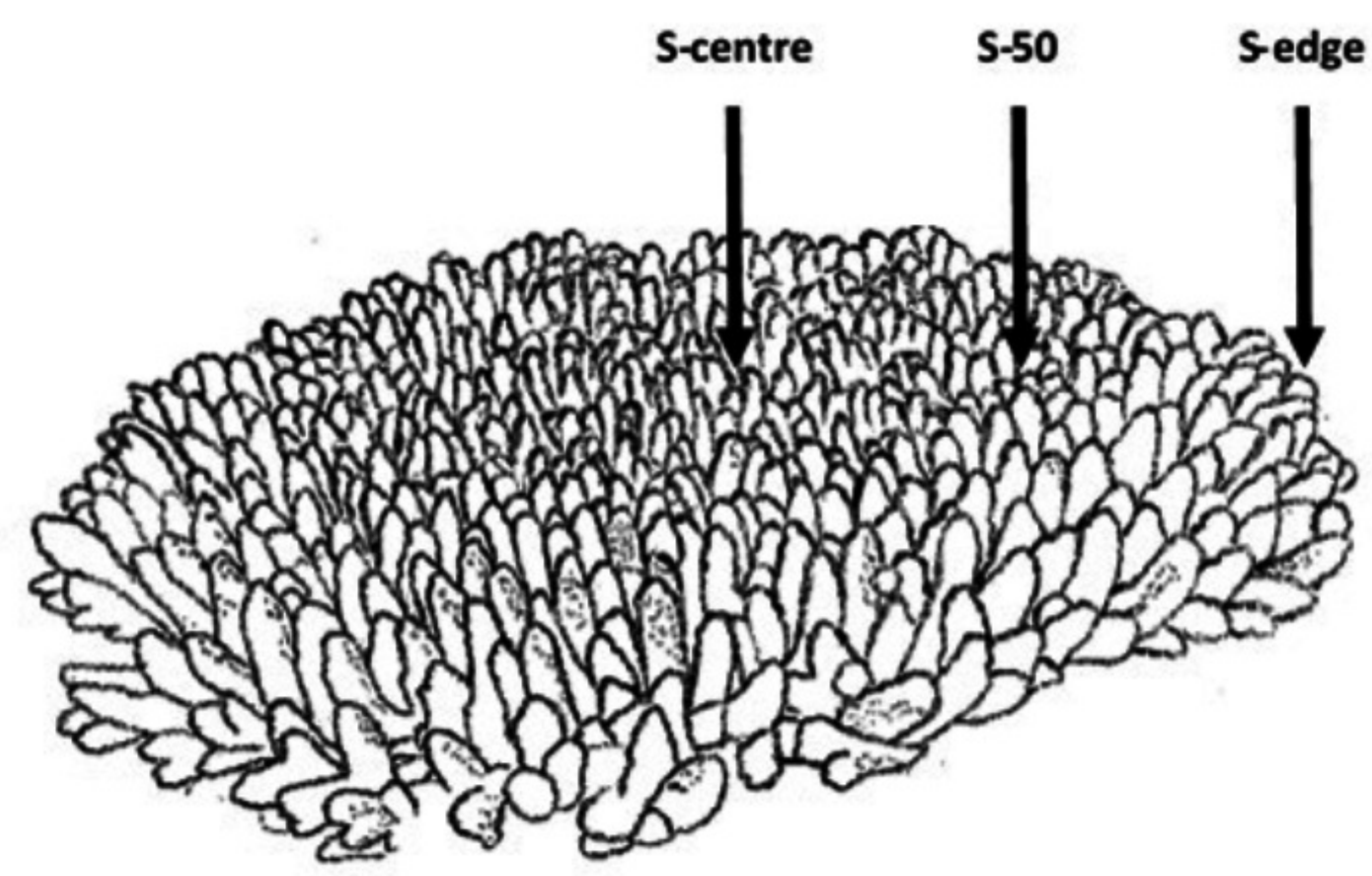




\section{Figure 2}

Proximate composition, energy content, and zooxanthellae density of distal intracolonial locations in two size classes of Acropora millepora colonies.

(a) Total lipid concentration, (b) Total protein concentration, (c) Total nitrogen-free extract concentration (NFE), (d) Total ash concentration, (e) Zooxanthellae density, (f) Energy content (using caloric enthalpies of lipid + protein). L-centre: larger colony centre, L-33: 33.3 $\%$ of the longitudinal radius length, L-66: $66.6 \%$ of the longitudinal radius length, L-edge: larger colony edge, S-centre: smaller colony centre, S-50: $50 \%$ of the longitudinal radius length, S-edge: smaller colony edge (S-edge). Values are presented as means \pm SEM. Letters in common denote no significant difference $(P<0.05)$. For each size class, $n=10$.
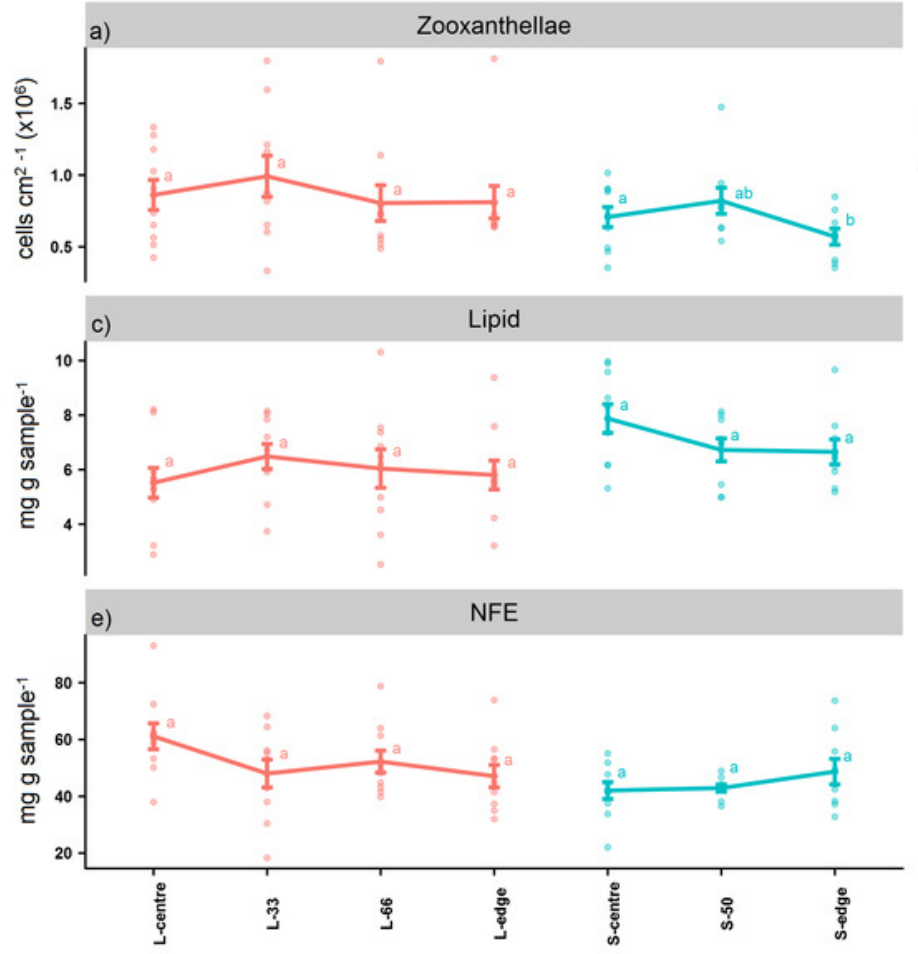

$$
\text { - Large - Small }
$$
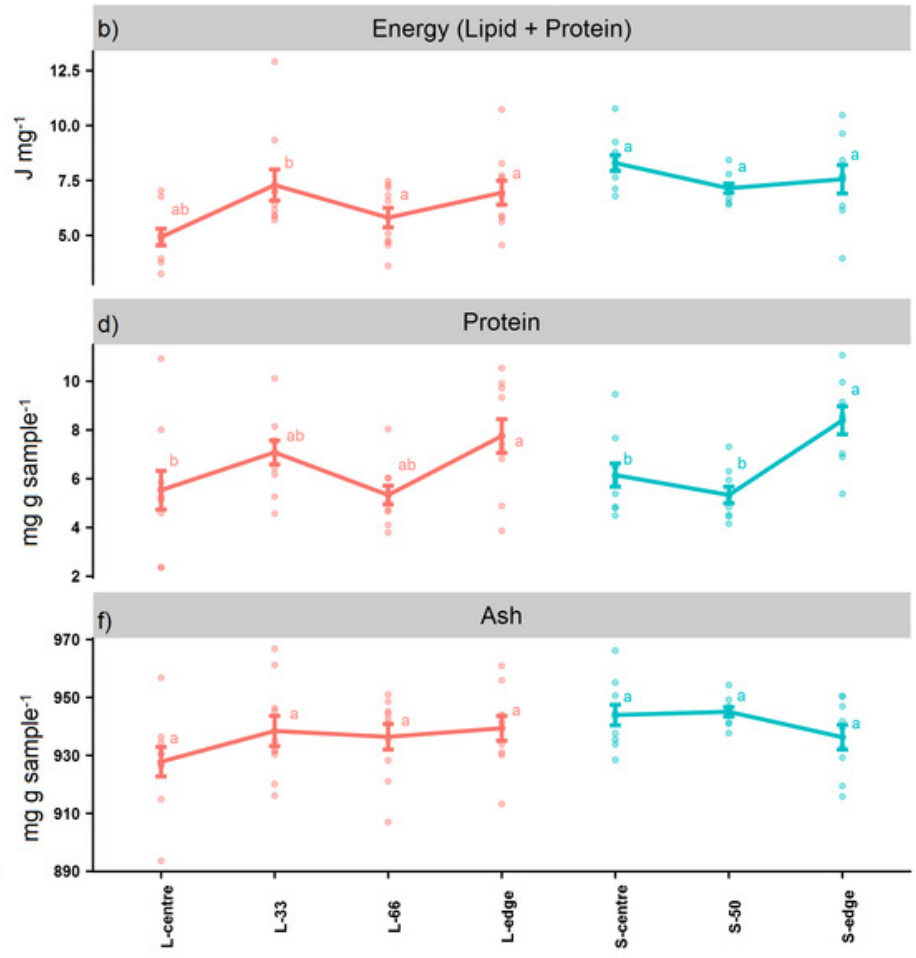


\section{Figure 3}

Lipid class composition - relative proportion of storage and structural lipids of distal intracolonial locations in two size classes of Acropora millepora colonies.

L-centre: larger colony centre, L-33: $33.3 \%$ of the longitudinal radius length, L-66: $66.6 \%$ of the longitudinal radius length, L-edge: larger colony edge, S-centre: smaller colony centre, S50: $50 \%$ of the longitudinal radius length, S-edge: smaller colony edge (S-edge). Values are presented as means \pm SEM. Letters in common denote no significant difference $(P<0.05)$. For each size class, $\mathrm{n}=10$.

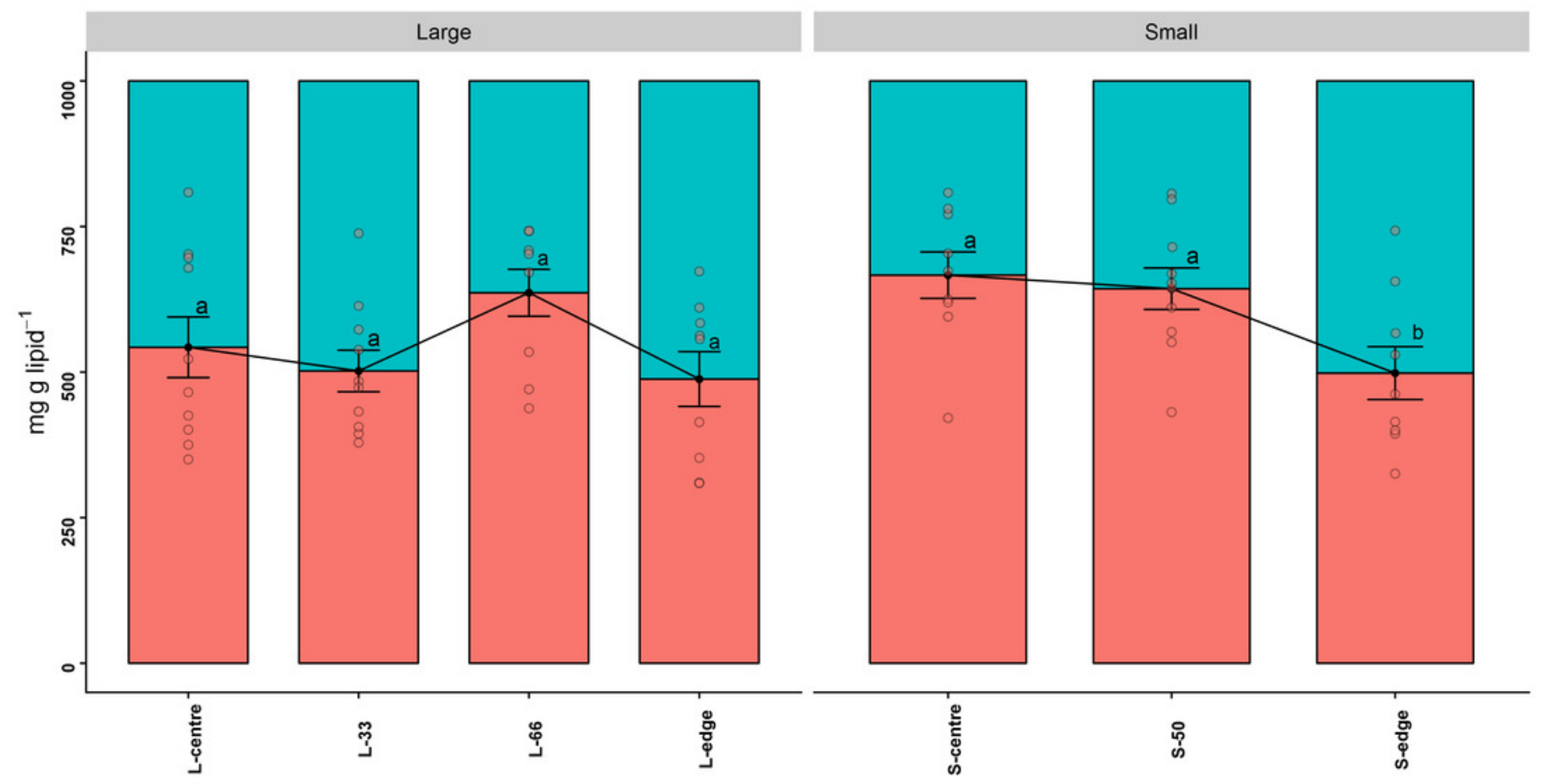

$\square$ Storage $\square$ Structural 


\section{Figure 4}

Linear discriminant analysis (LDA) a) score plot and b) biplot, showing overall fatty acid profile ( $\mathrm{mg} \mathrm{g} \mathrm{lipid}^{-1}$ ) of distal intracolonial locations in two size classes of Acropora millepora colonies.

L-centre: larger colony centre, L-33: 33.3\% of the longitudinal radius length, L-66: $66.6 \%$ of the longitudinal radius length, L-edge: larger colony edge, S-centre: smaller colony centre, S50: $50 \%$ of the longitudinal radius length, S-edge: smaller colony edge (S-edge). a) Ellipses show $95 \%$ confidence intervals for each treatment. b) Vectors show top fifteen individual fatty acids and fatty alcohols contributing to the overall variance between treatments. Colour gradient shows percentage contribution to LDA loadings. For each size class, $\mathrm{n}=10$.

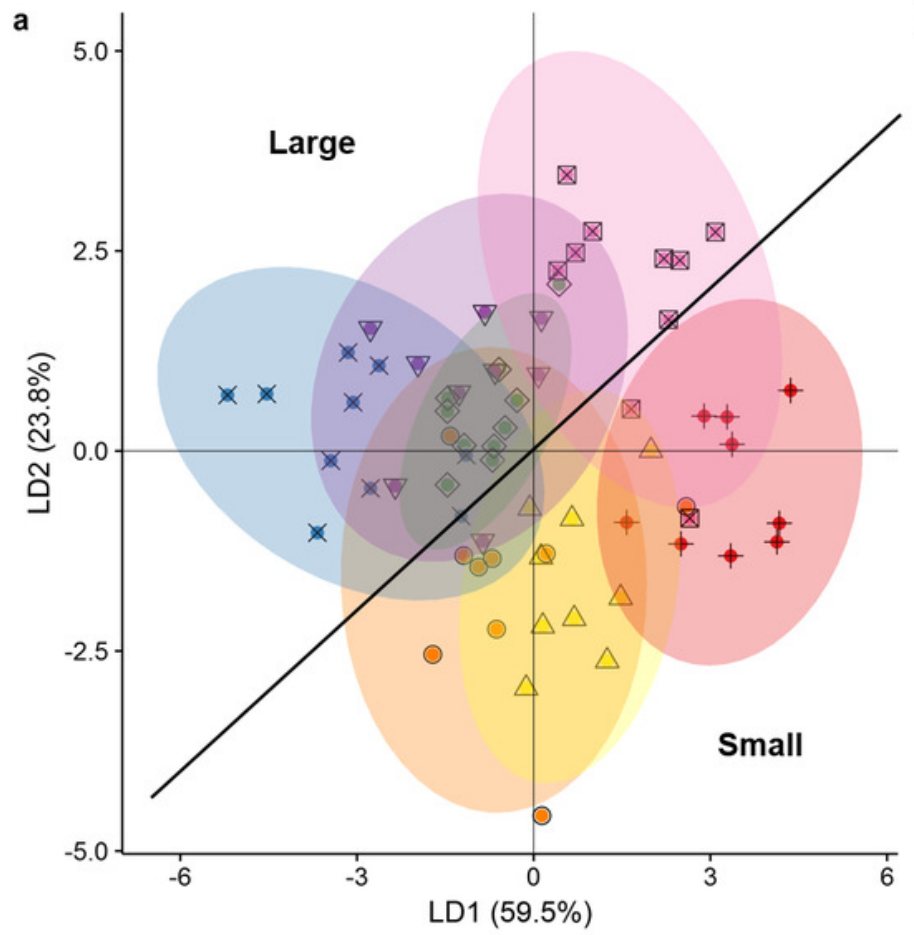

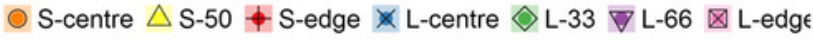

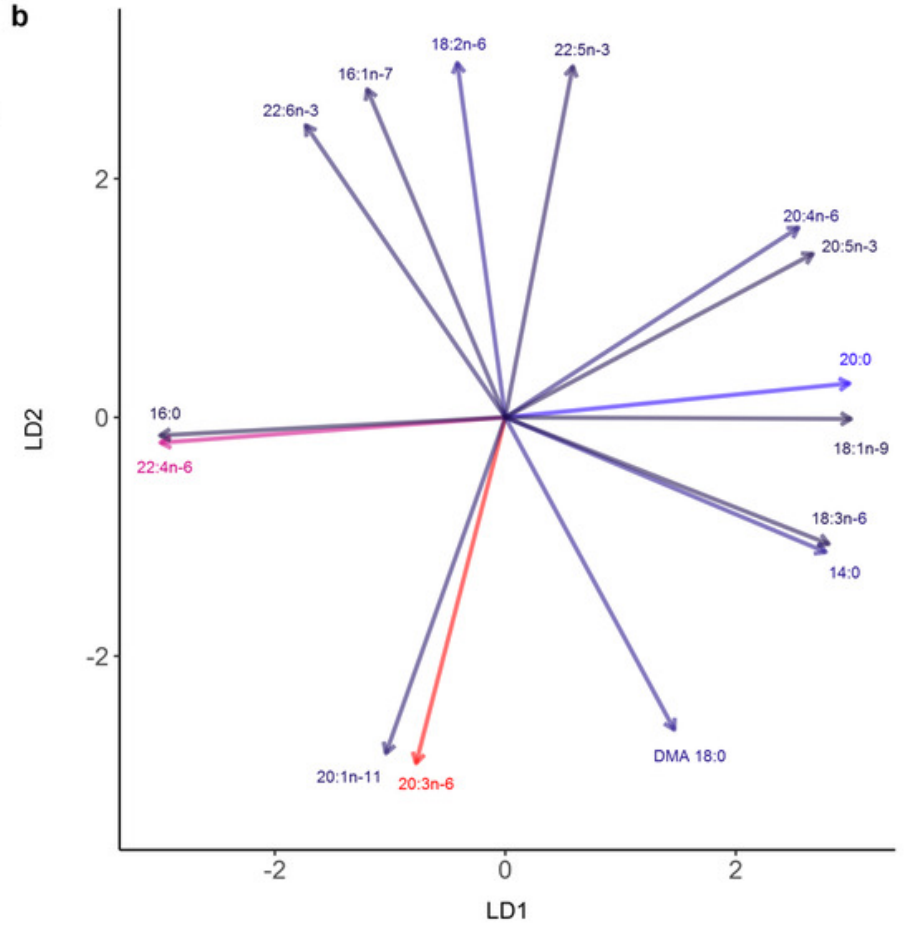

Loadings contribution (\%) 


\section{Table $\mathbf{1}$ (on next page)}

Lipid class composition ( $\mathrm{mg} \mathrm{g} \mathrm{lipid}^{-1}$ ) of distal intracolonial locations in two size classes of Acropora millepora colonies.

L-centre: large colony centre, L-33: 33.3\% of the longitudinal radius length, L-66: $66.6 \%$ of the longitudinal radius length, L-edge: large colony edge, S-centre: small colony centre, S-50: $50 \%$ of the longitudinal radius length, S-edge: small colony edge (S-edge). Values are presented as means \pm SEM. For each colony size, values in the same row size that do not share the same superscripts are significantly different $(P<0.05)$. 
Table 1

2 Lipid class composition ( $\mathrm{mg} \mathrm{g} \mathrm{lipid}^{-1}$ ) of distal intracolonial locations in two size classes of Acropora millepora colonies. L-centre:

3 large colony centre, L-33: 33.3\% of the longitudinal radius length, L-66: $66.6 \%$ of the longitudinal radius length, L-edge: large colony

4 edge, S-centre: small colony centre, S-50: 50\% of the longitudinal radius length, S-edge: small colony edge (S-edge). Values are

5 presented as means \pm SEM. For each colony size, values in the same row size that do not share the same superscripts are significantly

6 different $(P<0.05)$.

\begin{tabular}{|c|c|c|c|c|c|c|c|}
\hline \multirow[b]{2}{*}{ Lipid class (mg g lipid-1) } & \multicolumn{3}{|c|}{ Small } & \multicolumn{4}{|c|}{ Large } \\
\hline & Centre & $\mathrm{S}-50$ & Edge & Centre & L-33 & L-66 & Edge \\
\hline Wax ester & $114 \pm 15.9^{b}$ & $171 \pm 48.5^{\mathrm{a}}$ & $118 \pm 15.8^{\mathrm{ab}}$ & $194 \pm 92.3^{\mathrm{a}}$ & $130 \pm 7.71^{\mathrm{a}}$ & $125 \pm 9.88^{\mathrm{a}}$ & $119 \pm 6.77^{\mathrm{a}}$ \\
\hline Triacylglycerol & $499 \pm 94.1^{\mathrm{a}}$ & $411 \pm 92.8^{\mathrm{a}}$ & $311 \pm 94.9^{\mathrm{a}}$ & $270 \pm 123^{a}$ & $301 \pm 69.9^{\mathrm{a}}$ & $456 \pm 69.2^{\mathrm{a}}$ & $312 \pm 75.3^{\mathrm{ab}}$ \\
\hline Free fatty acid & $14.6 \pm 3.48^{\mathrm{a}}$ & $16.5 \pm 5.78^{\mathrm{a}}$ & $19 \pm 3.29^{a}$ & $20.1 \pm 7.05^{\mathrm{a}}$ & $18.3 \pm 2.73^{\mathrm{a}}$ & $17 \pm 3.16^{\mathrm{a}}$ & $22.2 \pm 2.08^{\mathrm{a}}$ \\
\hline 1,2-diacylglycerol & $39.1 \pm 13^{\mathrm{a}}$ & $44.5 \pm 13^{\mathrm{a}}$ & $50.6 \pm 14.5^{\mathrm{a}}$ & $58.5 \pm 19.4^{\mathrm{a}}$ & $52.7 \pm 22.1^{\mathrm{a}}$ & $38 \pm 10.7^{\mathrm{a}}$ & $34.5 \pm 14^{\mathrm{a}}$ \\
\hline Sterol & $44.9 \pm 9.17^{\mathrm{b}}$ & $48.5 \pm 8.31^{b}$ & $71.9 \pm 9.47^{\mathrm{a}}$ & $56.4 \pm 9.42^{\mathrm{a}}$ & $66 \pm 7.72^{\mathrm{a}}$ & $63.9 \pm 28^{\mathrm{a}}$ & $74.1 \pm 6.81^{\mathrm{a}}$ \\
\hline AMPL & $96.7 \pm 23^{b}$ & $100 \pm 20.6^{\mathrm{b}}$ & $150 \pm 25.6^{\mathrm{a}}$ & $118 \pm 21.3^{\mathrm{ab}}$ & $138 \pm 17^{\mathrm{a}}$ & $88.5 \pm 12.2^{b}$ & $145 \pm 27^{\mathrm{a}}$ \\
\hline Phosphatidylethanolamine & $49.9 \pm 9.51^{\mathrm{b}}$ & $54.7 \pm 9.57^{\mathrm{ab}}$ & $69.3 \pm 12.9^{a}$ & $70.5 \pm 14.1^{\mathrm{a}}$ & $68.9 \pm 17.5^{\mathrm{a}}$ & $54.5 \pm 8.15^{\mathrm{a}}$ & $73.4 \pm 9.82^{\mathrm{a}}$ \\
\hline Phosphatidylserine/phosphatidylinositol & $53.1 \pm 16.7^{\mathrm{b}}$ & $69 \pm 20^{\mathrm{ab}}$ & $89.6 \pm 15.2^{\mathrm{a}}$ & $89.7 \pm 25.7^{\mathrm{a}}$ & $95.1 \pm 22.3^{\mathrm{a}}$ & $69.1 \pm 12.9^{\mathrm{a}}$ & $92.9 \pm 16.5^{\mathrm{a}}$ \\
\hline Phosphatidylcholine & $77.3 \pm 19.2^{b}$ & $81.1 \pm 13.6^{\mathrm{ab}}$ & $115 \pm 20.3^{\mathrm{a}}$ & $103 \pm 19.4^{\mathrm{a}}$ & $116 \pm 15.3^{\mathrm{a}}$ & $72.6 \pm 7.72^{b}$ & $121 \pm 16.5^{\mathrm{a}}$ \\
\hline Lysophosphatidylcholine & $11.7 \pm 11.2^{\mathrm{a}}$ & $3.12 \pm 5.7^{\mathrm{a}}$ & $6.05 \pm 10.5^{\mathrm{a}}$ & $19.3 \pm 14.5^{\mathrm{a}}$ & $13.5 \pm 14.8^{\mathrm{a}}$ & $15.1 \pm 12^{\mathrm{a}}$ & $6.1 \pm 9.15^{\mathrm{a}}$ \\
\hline$\sum$ Storage & $66.6 \pm 6.91^{\mathrm{a}}$ & $64.3 \pm 6.5^{\mathrm{a}}$ & $49.8 \pm 7.85^{\mathrm{b}}$ & $54.3 \pm 8.23^{\mathrm{a}}$ & $50.2 \pm 5.65^{\mathrm{a}}$ & $63.6 \pm 6.05^{\mathrm{a}}$ & $48.8 \pm 7.05^{\mathrm{a}}$ \\
\hline$\sum$ Structural & $33.4 \pm 6.91^{\mathrm{b}}$ & $35.7 \pm 6.5^{\mathrm{b}}$ & $50.2 \pm 7.85^{\mathrm{a}}$ & $45.7 \pm 8.23^{\mathrm{a}}$ & $49.8 \pm 5.65^{\mathrm{a}}$ & $36.4 \pm 6.05^{\mathrm{a}}$ & $51.2 \pm 7.05^{\mathrm{a}}$ \\
\hline Storage:Structural & $2.34 \pm 0.66^{\mathrm{a}}$ & $2.1 \pm 0.64^{\mathrm{ab}}$ & $1.17 \pm 0.45^{\mathrm{b}}$ & $1.55 \pm 0.59^{\mathrm{a}}$ & $1.14 \pm 0.33^{\mathrm{a}}$ & $1.99 \pm 0.42^{\mathrm{a}}$ & $1.09 \pm 0.29^{\mathrm{a}}$ \\
\hline
\end{tabular}

7 


\section{Table 2 (on next page)}

Fatty acid and fatty alcohol composition ( $\mathrm{mg} \mathrm{g} \mathrm{lipid}^{-1}$ ) of distal intracolonial locations in two size classes of Acropora millepora colonies.

L-centre: large colony centre, L-33: $33.3 \%$ of the longitudinal radius length, L-66: $66.6 \%$ of the longitudinal radius length, L-edge: large colony edge, S-centre: small colony centre, S-50: $50 \%$ of the longitudinal radius length, S-edge: small colony edge (S-edge). Values are presented as means \pm SEM. For each colony size, values in the same row size that do not share the same superscripts are significantly different $(P<0.05)$. 
Table 2

2 Fatty acid and fatty alcohol composition $\left(\mathrm{mg} \mathrm{g} \mathrm{lipid}^{-1}\right)$ of distal intracolonial locations in two size classes of Acropora millepora

3 colonies. L-centre: large colony centre, L-33: $33.3 \%$ of the longitudinal radius length, L-66: $66.6 \%$ of the longitudinal radius length,

4 L-edge: large colony edge, S-centre: small colony centre, S-50: 50\% of the longitudinal radius length, S-edge: small colony edge (S-

5 edge). Values are presented as means \pm SEM. For each colony size, values in the same row size that do not share the same superscripts

6 are significantly different $(P<0.05)$.

\begin{tabular}{|c|c|c|c|c|c|c|c|}
\hline \multirow[b]{2}{*}{ Fatty Acids ( $m g$ g lipid $\left.{ }^{-1}\right)$} & \multicolumn{3}{|c|}{ Small } & \multicolumn{4}{|c|}{ Large } \\
\hline & Centre & S-50 & Edge & Centre & L-33 & L-66 & Edge \\
\hline $14: 0$ & $25.2 \pm 4.32^{\mathrm{a}}$ & $21.9 \pm 2.71^{\mathrm{a}}$ & $14.4 \pm 3.14^{b}$ & $21.2 \pm 3.95^{\mathrm{ab}}$ & $17.8 \pm 2.97^{\mathrm{ab}}$ & $25.8 \pm 3.97^{\mathrm{a}}$ & $14.9 \pm 2.52^{\mathrm{b}}$ \\
\hline $16: 0$ & $224 \pm 38.6^{a}$ & $192 \pm 22^{\mathrm{ab}}$ & $134 \pm 29.4^{b}$ & $188 \pm 32.2^{\mathrm{ab}}$ & $159 \pm 23.4^{b}$ & $238 \pm 32.4^{\mathrm{a}}$ & $144 \pm 26.2^{b}$ \\
\hline $18: 0$ & $38.1 \pm 6.19^{\mathrm{a}}$ & $33.6 \pm 4.22^{\mathrm{a}}$ & $33.5 \pm 3.88^{\mathrm{a}}$ & $30.8 \pm 3.11^{\mathrm{a}}$ & $29.4 \pm 3.64^{\mathrm{a}}$ & $33.6 \pm 3.66^{\mathrm{a}}$ & $33.1 \pm 3.76^{\mathrm{a}}$ \\
\hline$\sum$ SFA & $296 \pm 48.9^{a}$ & $255 \pm 28^{\mathrm{ab}}$ & $189 \pm 35.9^{b}$ & $248 \pm 37.5^{\mathrm{ab}}$ & $214 \pm 28.2^{b}$ & $306 \pm 38.9^{a}$ & $199 \pm 31.3^{b}$ \\
\hline 16:0-OH & $68.4 \pm 13^{a}$ & $59.8 \pm 9.22^{\mathrm{a}}$ & $37.7 \pm 9.63^{b}$ & $55.1 \pm 11.7^{\mathrm{ab}}$ & $46.9 \pm 8.75^{b}$ & $75.8 \pm 10.2^{\mathrm{a}}$ & $44 \pm 9.84^{b}$ \\
\hline 18:1n-9 & $18.4 \pm 3.41^{\mathrm{a}}$ & $16.4 \pm 2.42^{\mathrm{a}}$ & $11.1 \pm 2.72^{\mathrm{b}}$ & $19.5 \pm 3.76^{\mathrm{ab}}$ & $15.8 \pm 1.97^{\mathrm{ab}}$ & $24.4 \pm 3.71^{\mathrm{a}}$ & $14.2 \pm 2.93^{\mathrm{b}}$ \\
\hline 20:1n-11 & $14.3 \pm 1.9^{\mathrm{a}}$ & $11.8 \pm 1.23^{\mathrm{ab}}$ & $9.53 \pm 1.36^{\mathrm{b}}$ & $12.8 \pm 1.48^{\mathrm{a}}$ & $11.8 \pm 1.37^{\mathrm{a}}$ & $14.6 \pm 1.74^{\mathrm{a}}$ & $11.1 \pm 1.2^{\mathrm{a}}$ \\
\hline$\sum$ MUFA & $51.2 \pm 6.99^{\mathrm{a}}$ & $44.5 \pm 4.44^{\mathrm{ab}}$ & $32.8 \pm 5.73^{b}$ & $48.8 \pm 7.54^{\mathrm{ab}}$ & $41.9 \pm 4.75^{\mathrm{b}}$ & $59.4 \pm 7.49^{\mathrm{a}}$ & $38.7 \pm 5.7^{\mathrm{b}}$ \\
\hline $18: 3 n-6$ & $24.8 \pm 4.38^{\mathrm{a}}$ & $21.2 \pm 2.34^{\mathrm{a}}$ & $13.4 \pm 3.18^{b}$ & $20.1 \pm 3.87^{\mathrm{ab}}$ & $17 \pm 2.3^{b}$ & $26.6 \pm 3.48^{a}$ & $15.7 \pm 3.28^{b}$ \\
\hline $20: 4 n-6$ & $8.22 \pm 1.4^{b}$ & $8.3 \pm 1.63^{\mathrm{ab}}$ & $11.2 \pm 1.26^{\mathrm{a}}$ & $8.39 \pm 1.6^{b}$ & $8.79 \pm 1.34^{b}$ & $8.13 \pm 0.81^{b}$ & $12.5 \pm 1.64^{\mathrm{a}}$ \\
\hline $20: 5 n-3$ & $21.4 \pm 1.85^{\mathrm{a}}$ & $19.6 \pm 2.72^{\mathrm{a}}$ & $21.7 \pm 2.76^{\mathrm{a}}$ & $19.1 \pm 1.5^{\mathrm{a}}$ & $19.7 \pm 2.15^{a}$ & $20.9 \pm 1.93^{\mathrm{a}}$ & $23.4 \pm 2.1^{\mathrm{a}}$ \\
\hline $22: 6 n-3$ & $16.9 \pm 3.02^{\mathrm{a}}$ & $14.5 \pm 2.08^{\mathrm{ab}}$ & $11.1 \pm 2.29^{b}$ & $13.6 \pm 2.4^{\mathrm{a}}$ & $11.9 \pm 1.88^{a}$ & $17 \pm 2.47^{\mathrm{a}}$ & $12.3 \pm 1.81^{\mathrm{a}}$ \\
\hline$\sum$ PUFA & $164 \pm 21^{\mathrm{a}}$ & $146 \pm 15.9^{a b}$ & $119 \pm 17.6^{\mathrm{b}}$ & $142 \pm 16.5^{\mathrm{ab}}$ & $128 \pm 14^{b}$ & $175 \pm 19.5^{\mathrm{a}}$ & $136 \pm 16.2^{b}$ \\
\hline$\sum$ Fatty alcohol & $75.4 \pm 13.3^{\mathrm{a}}$ & $66.5 \pm 9.66^{\mathrm{ab}}$ & $44.6 \pm 10.2^{b}$ & $61.4 \pm 11.9^{b}$ & $53.1 \pm 8.79^{b}$ & $82.9 \pm 10.8^{a}$ & $51.7 \pm 10.1^{\mathrm{b}}$ \\
\hline Total & $519 \pm 75.1^{\mathrm{a}}$ & $452 \pm 46.8^{\mathrm{ab}}$ & $347 \pm 58.6^{b}$ & $445 \pm 61.3^{\mathrm{ab}}$ & $391 \pm 46.1^{b}$ & $547 \pm 66^{\mathrm{a}}$ & $382 \pm 52.6^{b}$ \\
\hline$\sum n-3$ PUFA & $44.9 \pm 4.65^{\mathrm{a}}$ & $40.2 \pm 5.04^{\mathrm{a}}$ & $39.3 \pm 5.16^{\mathrm{a}}$ & $38.8 \pm 3.31^{\mathrm{a}}$ & $37.8 \pm 4.04^{\mathrm{a}}$ & $44.5 \pm 4.94^{\mathrm{a}}$ & $43.1 \pm 3.93^{\mathrm{a}}$ \\
\hline
\end{tabular}




\section{Table 3 (on next page)}

Fatty acid and fatty alcohol composition (\% fatty acids) of distal intracolonial locations in two size classes of Acropora millepora colonies.

L-centre: large colony centre, L-33: 33.3\% of the longitudinal radius length, L-66: $66.6 \%$ of the longitudinal radius length, L-edge: large colony edge, S-centre: small colony centre, S-50: $50 \%$ of the longitudinal radius length, S-edge: small colony edge (S-edge). Values are presented as means \pm SEM. For each colony size, values in the same row size that do not share the same superscripts are significantly different $(P<0.05)$. 


\section{Table 3}

2 Fatty acid and fatty alcohol composition (\% fatty acids) of distal intracolonial locations in two size classes of Acropora millepora

3 colonies. L-centre: large colony centre, L-33: $33.3 \%$ of the longitudinal radius length, L-66: $66.6 \%$ of the longitudinal radius length,

4 L-edge: large colony edge, S-centre: small colony centre, S-50: 50\% of the longitudinal radius length, S-edge: small colony edge (S-

5 edge). Values are presented as means \pm SEM. For each colony size, values in the same row size that do not share the same superscripts

6 are significantly different $(P<0.05)$.

\begin{tabular}{|c|c|c|c|c|c|c|c|}
\hline \multirow[b]{2}{*}{ Fatty Acids (\% fatty acids) } & \multicolumn{3}{|c|}{ Small } & \multicolumn{4}{|c|}{ Large } \\
\hline & Centre & S-50 & Edge & Centre & L-33 & L-66 & Edge \\
\hline $14: 0$ & $4.8 \pm 0.16^{\mathrm{a}}$ & $4.83 \pm 0.22^{\mathrm{a}}$ & $4.05 \pm 0.29^{b}$ & $4.66 \pm 0.29^{a}$ & $4.49 \pm 0.31^{\mathrm{a}}$ & $4.67 \pm 0.26^{\mathrm{a}}$ & $3.83 \pm 0.21^{\mathrm{b}}$ \\
\hline $16: 0$ & $42.6 \pm 1.68^{\mathrm{a}}$ & $42.3 \pm 1.74^{\mathrm{a}}$ & $37.5 \pm 2.69^{b}$ & $41.4 \pm 1.68^{\mathrm{a}}$ & $40.4 \pm 1.46^{\mathrm{ab}}$ & $43.2 \pm 0.85^{\mathrm{a}}$ & $36.8 \pm 2.2^{b}$ \\
\hline $18: 0$ & $7.43 \pm 0.85^{b}$ & $7.45 \pm 0.63^{b}$ & $10 \pm 1.05^{\mathrm{a}}$ & $7.27 \pm 0.92^{\mathrm{ab}}$ & $7.66 \pm 0.77^{\mathrm{ab}}$ & $6.23 \pm 0.56^{\mathrm{b}}$ & $8.92 \pm 0.8^{\mathrm{a}}$ \\
\hline$\sum$ SFA & $56.6 \pm 1.39^{\mathrm{a}}$ & $56.3 \pm 1.52^{\mathrm{a}}$ & $53.8 \pm 1.79^{\mathrm{a}}$ & $55.2 \pm 1.17^{\mathrm{a}}$ & $54.6 \pm 1.13^{\mathrm{ab}}$ & $55.6 \pm 0.79^{\mathrm{a}}$ & $51.6 \pm 1.74^{b}$ \\
\hline 16:0-OH & $13 \pm 0.76^{\mathrm{a}}$ & $13.1 \pm 0.88^{a}$ & $10.4 \pm 1.13^{\mathrm{b}}$ & $12 \pm 1.12^{\mathrm{ab}}$ & $11.8 \pm 1.11^{\mathrm{ab}}$ & $13.8 \pm 0.5^{\mathrm{a}}$ & $11.1 \pm 1.18^{\mathrm{b}}$ \\
\hline 18:1n-9 & $3.59 \pm 0.62^{\mathrm{a}}$ & $3.67 \pm 0.47^{\mathrm{a}}$ & $3.17 \pm 0.51^{\mathrm{a}}$ & $4.27 \pm 0.36^{\mathrm{a}}$ & $4.09 \pm 0.35^{\mathrm{a}}$ & $4.41 \pm 0.27^{\mathrm{a}}$ & $3.7 \pm 0.41^{\mathrm{a}}$ \\
\hline $20: 1 n-11$ & $2.77 \pm 0.17^{\mathrm{a}}$ & $2.63 \pm 0.23^{\mathrm{a}}$ & $2.81 \pm 0.23^{\mathrm{a}}$ & $2.93 \pm 0.25^{\mathrm{a}}$ & $3.07 \pm 0.26^{\mathrm{a}}$ & $2.7 \pm 0.18^{\mathrm{a}}$ & $2.99 \pm 0.25^{\mathrm{a}}$ \\
\hline$\sum$ MUFA & $9.97 \pm 0.95^{\mathrm{a}}$ & $9.92 \pm 0.68^{\mathrm{a}}$ & $9.49 \pm 0.71^{\mathrm{a}}$ & $10.9 \pm 0.35^{\mathrm{a}}$ & $10.8 \pm 0.4^{\mathrm{a}}$ & $10.8 \pm 0.23^{\mathrm{a}}$ & $10.1 \pm 0.4^{\mathrm{a}}$ \\
\hline $18: 3 n-6$ & $4.31 \pm 0.68^{\mathrm{a}}$ & $4.39 \pm 0.61^{\mathrm{a}}$ & $6.59 \pm 1.14^{b}$ & $4.57 \pm 0.64^{\mathrm{ab}}$ & $5.18 \pm 0.62^{\mathrm{a}}$ & $3.91 \pm 0.33^{\mathrm{ab}}$ & $6.47 \pm 0.87^{b}$ \\
\hline $20: 4 n-6$ & $3.23 \pm 0.24^{b}$ & $3.17 \pm 0.26^{b}$ & $3.14 \pm 0.16^{\mathrm{a}}$ & $3.01 \pm 0.2^{b}$ & $2.99 \pm 0.2^{\mathrm{ab}}$ & $3.08 \pm 0.13^{b}$ & $3.23 \pm 0.2^{\mathrm{a}}$ \\
\hline $20: 5 n-3$ & $4.73 \pm 0.44^{b}$ & $4.72 \pm 0.31^{\mathrm{b}}$ & $3.76 \pm 0.43^{\mathrm{a}}$ & $4.4 \pm 0.32^{b}$ & $4.32 \pm 0.16^{\mathrm{ab}}$ & $4.85 \pm 0.2^{b}$ & $4.01 \pm 0.36^{\mathrm{a}}$ \\
\hline $22: 6 n-3$ & $1.76 \pm 0.55^{\mathrm{a}}$ & $1.88 \pm 0.44^{\mathrm{a}}$ & $3.52 \pm 0.76^{\mathrm{a}}$ & $2.13 \pm 0.59^{\mathrm{a}}$ & $2.37 \pm 0.45^{\mathrm{a}}$ & $1.55 \pm 0.23^{\mathrm{a}}$ & $3.54 \pm 0.7^{\mathrm{a}}$ \\
\hline$\sum$ PUFA & $19 \pm 1.67^{b}$ & $19.2 \pm 1.52^{b}$ & $24.2 \pm 2.54^{\mathrm{a}}$ & $20.5 \pm 1.84^{b}$ & $21.2 \pm 1.72^{\mathrm{ab}}$ & $18.3 \pm 0.77^{b}$ & $25 \pm 2.36^{\mathrm{a}}$ \\
\hline$\sum$ Fatty alcohol & $14.4 \pm 0.62^{\mathrm{a}}$ & $14.5 \pm 0.78^{\mathrm{a}}$ & $12.5 \pm 0.91^{\mathrm{b}}$ & $13.4 \pm 1.01^{\mathrm{a}}$ & $13.4 \pm 0.98^{\mathrm{a}}$ & $15.1 \pm 0.49^{\mathrm{a}}$ & $13.2 \pm 0.95^{\mathrm{a}}$ \\
\hline Total (\% lipid) & $51.9 \pm 7.5^{\mathrm{a}}$ & $45.2 \pm 4.7^{\mathrm{a}}$ & $34.7 \pm 5.9^{b}$ & $44.5 \pm 6.1^{\mathrm{ab}}$ & $39.1 \pm 4.6^{\mathrm{b}}$ & $54.7 \pm 6.6^{\mathrm{a}}$ & $38.2 \pm 5.2^{b}$ \\
\hline
\end{tabular}


$\sum$ n-3 PUFA

$\sum$ n-6 PUFA
$8.87 \pm 0.86^{\mathrm{b}} \quad 8.92 \pm 0.91^{\mathrm{b}}$

$5.39 \pm 1.07^{\mathrm{b}} \quad 5.57 \pm 0.84^{\mathrm{b}}$

$11.7 \pm 1.43^{\mathrm{a}}$
$8.67 \pm 1.46^{\mathrm{a}}$

$9.03 \pm 0.74^{\mathrm{b}}$

$7 \pm 1.47^{\mathrm{ab}}$
$9.81 \pm 0.8^{\mathrm{ab}}$

$7.04 \pm 1.02^{\mathrm{ab}}$
$8.21 \pm 0.42^{\mathrm{b}}$

$5.2 \pm 0.48^{\mathrm{b}}$
$11.7 \pm 1.26^{\mathrm{a}}$

$9.21 \pm 1.4^{\mathrm{a}}$ 